\title{
Extensional Flow during Gravitational Collapse: A Tool for Setting Plate Convergence (Padrón Migmatitic Dome, Variscan Belt, NW Iberia)
}

\author{
Rubén Díez Fernández, ${ }^{1, \star}$ José R. Martínez Catalán, ${ }^{1}$ \\ Juan Gómez Barreiro, ${ }^{1}$ and Ricardo Arenas ${ }^{2}$
1. Departamento de Geología, Universidad de Salamanca, 37008 Salamanca, Spain; 2. Departamento de Petrología y Geoquímica and Instituto de Geología Económica, Universidad Complutensel \\ Consejo Superior de Investigaciones Científicas, 28040 Madrid, Spain
}

\begin{abstract}
A B S T R A C T
Plate convergence analysis in collisional orogens is usually based on the study of major contractional structures and strike-slip shear zones. Here we show how the structural analysis of extensional structures may report the regional or far stress field during relatively local, gravity-driven extensional collapse of a thickened continental crust and how this information may be used to constrain the broad vectors of plate convergence at that time. The Padrón migmatitic dome is a synconvergent extensional system developed in the axial zone of the Variscan belt exposed in the NW part of the Iberian Massif of Spain. This system affected the allochthonous and autochthonous sequences involved in Pangaea's assembly in Southern Europe. It includes three major extensional shear zones, which have been analyzed in detail to provide a wide ground data set for the discussion of the proposed model. The tectonic flow in the Padrón migmatitic dome and in other coeval structures is characterized by vectors ranging from parallel to oblique, in the latter case with a counterclockwise azimuth in relation to the trend of the orogenic belt. Our model suggests that the extensional collapse of the Variscan belt in NW Iberia would have developed if the convergence between Gondwana and Laurussia had not stopped and that it would have included a dextral component.
\end{abstract}

\section{Introduction}

Setting the vectors of plate convergence in orogeny has been one of the main goals of geology for decades. Modern observations (e.g., GPS measurements) and extensive geophysical data provide the young and active settings with reliable vectors (McCaffrey 1996; McCaffrey et al. 2000; Wu et al. 2009). However, pre-Cenozoic mountain belts lack these data, or the data are heavily distorted. Notwithstanding the absence of such precise information in ancient mountain belts, different approaches have been used to decipher the relative movement between colliding plates, such as paleomagnetism, paleobiostratigraphy, matching of stratigraphic sections and crustal provinces, provenance analysis of sedimentary detritus, or kinematic analysis of selected shear zones (Cocks and

\footnotetext{
Manuscript received March 23, 2011; accepted September 13, 2011.

* Author for correspondence; e-mail: georuben@usal.es.
}

Fortey 1982; Martínez Catalán 1990; Torsvik et al. 1996; Fernández-Suárez et al. 2002; Winchester et al. 2002; Fortey and Cocks 2003; Krawczyk et al. 2008). Although this information is less precise than that extracted from active or recent settings, it may constrain the relative position of continents back in time, allowing the ancient land mass distribution to be tentatively restored (e.g., Stampfli and Borel 2002).

Mountain belts raised from continent-continent collision have a long-term tectonic history. This fact allows tracing of the interaction between colliding plates throughout time by the analysis of their successive phases of deformation. However, each main tectonic event affecting a collisional belt has its own limitations to be used as a tracer. For example, the record of continental subduction, which would potentially characterize early plate convergence, is usually blurred during exhumation (Le Bayon and Ballevre 2006; Hacker et al. 2010; 


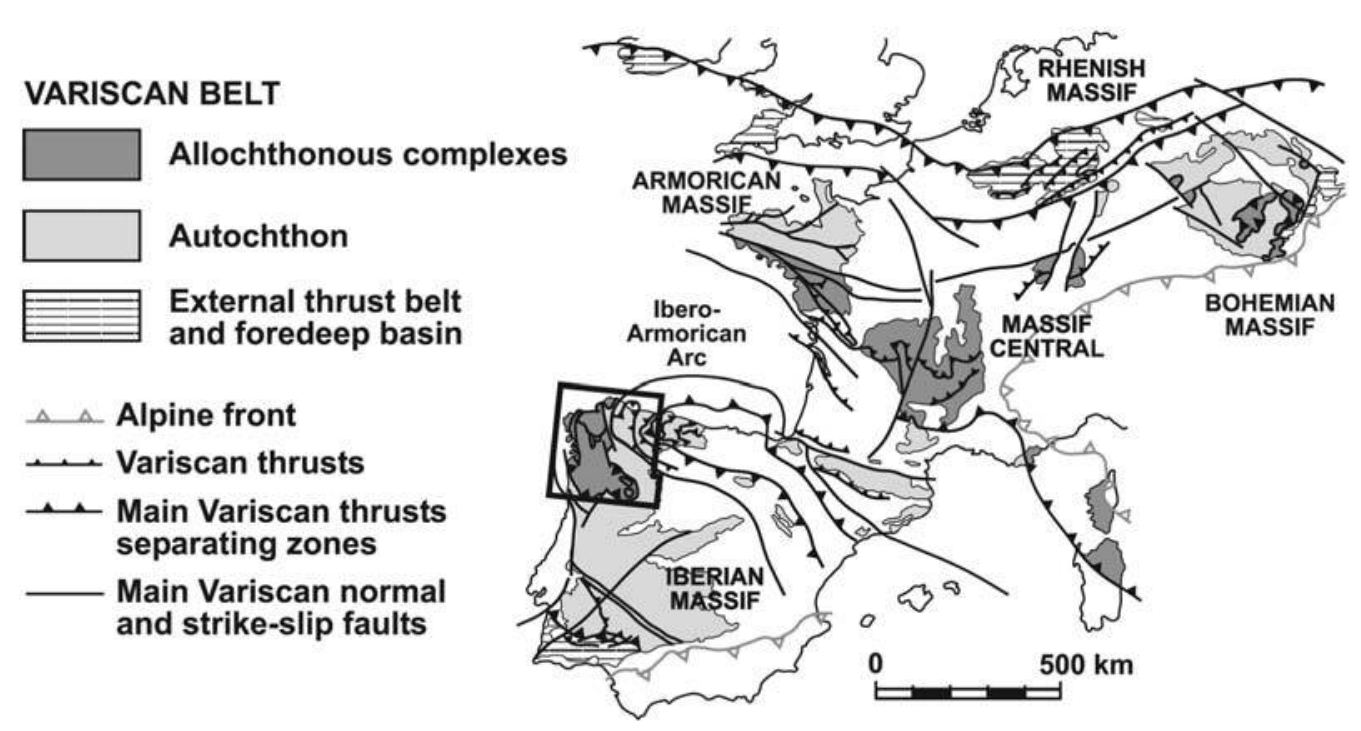

Figure 1. Synthesis of the major domains of the Variscan belt and location of the study area. A color version of this figure is available in the online edition or from the Journal of Geology office.

Díez Fernández et al. 2011). Because of orogen-scale deformation partitioning, crustal thickening and terrane accretion may not account for the lateral component of convergence, which might be taken by independent strike-slip shear zones (Beck 1983; McCaffrey 1992; Platt 1993). Large strike-slip shear zones must be considered one of the tools to set relative plate movements (e.g., Shelley and Bossiere 2002), but a good general picture is required to identify conjugated faults related to block extrusion or escape tectonics (e.g., Tapponnier and Molnar 1979; Tapponnier et al. 1982). Furthermore, major shear zones may show evidence of long-term activity (Miller et al. 2001) with changing kinematics and may undergo reworking by other shear zones of the same or different type, then providing reliable data for only the last pulses of continental collision.

Facing such a complex scenario, the analysis of gravitational collapse would help to reinforce or refine a given model of convergence. Gravitydriven tectonic flow may develop at any time in collisional belts. However, extensional collapse caused by thermal disequilibrium requires significant crustal thickening (Rey et al. 2001 and references therein), which is usually reached once the boundaries of the involved continents are sealed, blocking most of the along-strike displacement through the suture zone. In this article, the kinematic analysis of the structures developed during the extensional collapse is explored as an additional tool to set previous plate convergence vectors. We have focused on the example of the Padrón migmatitic dome, a synconvergent extensional system developed in the axial zone of the Variscan belt exposed in the NW section of the Iberian Massif of Spain. The tectonostratigraphic, metamorphic, and structural frameworks concerning this macrostructure will be described to provide an extensive ground data set for the discussion of the proposed model.

\section{Geological Setting}

The Variscan belt is a Devonian-Carboniferous orogen generated during the progressive collision of Gondwana and Laurussia following the closure of the Rheic Ocean (Matte 1991; Martínez Catalán et al. 2007). The structural pile of the NW section of the Iberian Massif preserves the main Paleozoic paleogeographic domains of the northern Gondwana margin, with those representing the peripheral and outermost realms placed on top (fig. 1; Martínez Catalán et al. 2009).

In the uppermost structural position, the allochthonous complexes are a collage of exotic terranes with ophiolites and high-pressure rocks that delineates the Pangaea's suture in southern Europe (Martínez Catalán et al. 1997). They are a nappe stack of allochthonous units, partly obducted onto the Gondwana mainland and folded into regional upright structures (figs. 2, 3; Martínez Catalán et al. 2002). Three main tectonometamorphic units are recognized (figs. 2, 3). The upper units are pieces of a Cambro-Ordovician ensialic island arc detached from Gondwana (Abati et al. 1999), while the middle units are ophiolitic and represent the 


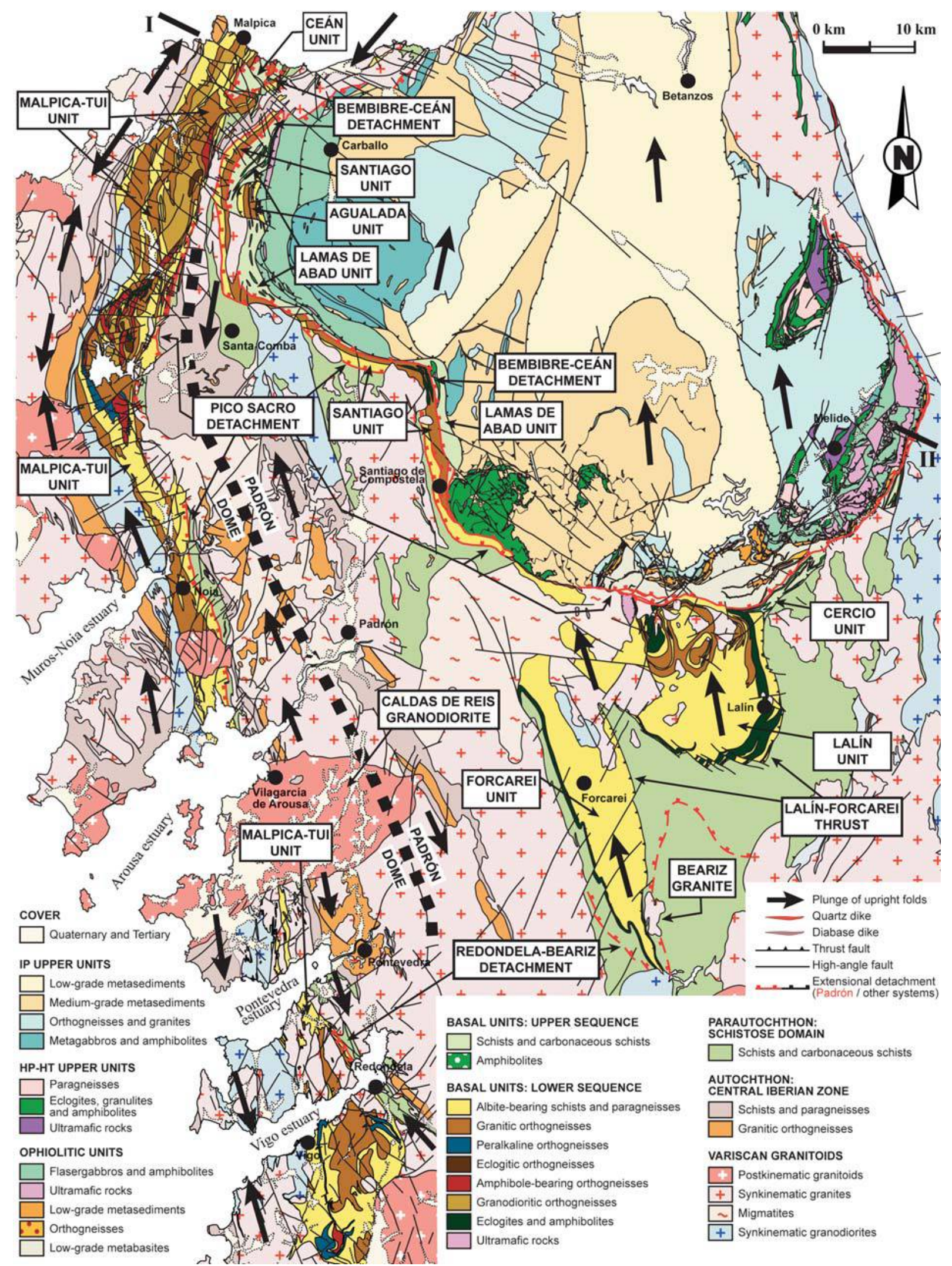

Figure 2. Map showing the allochthonous complexes of Ordenes and Malpica-Tui in Galicia, NW Spain. The distribution of the basal allochthonous units and the structures referred to in the text are included with their names. 


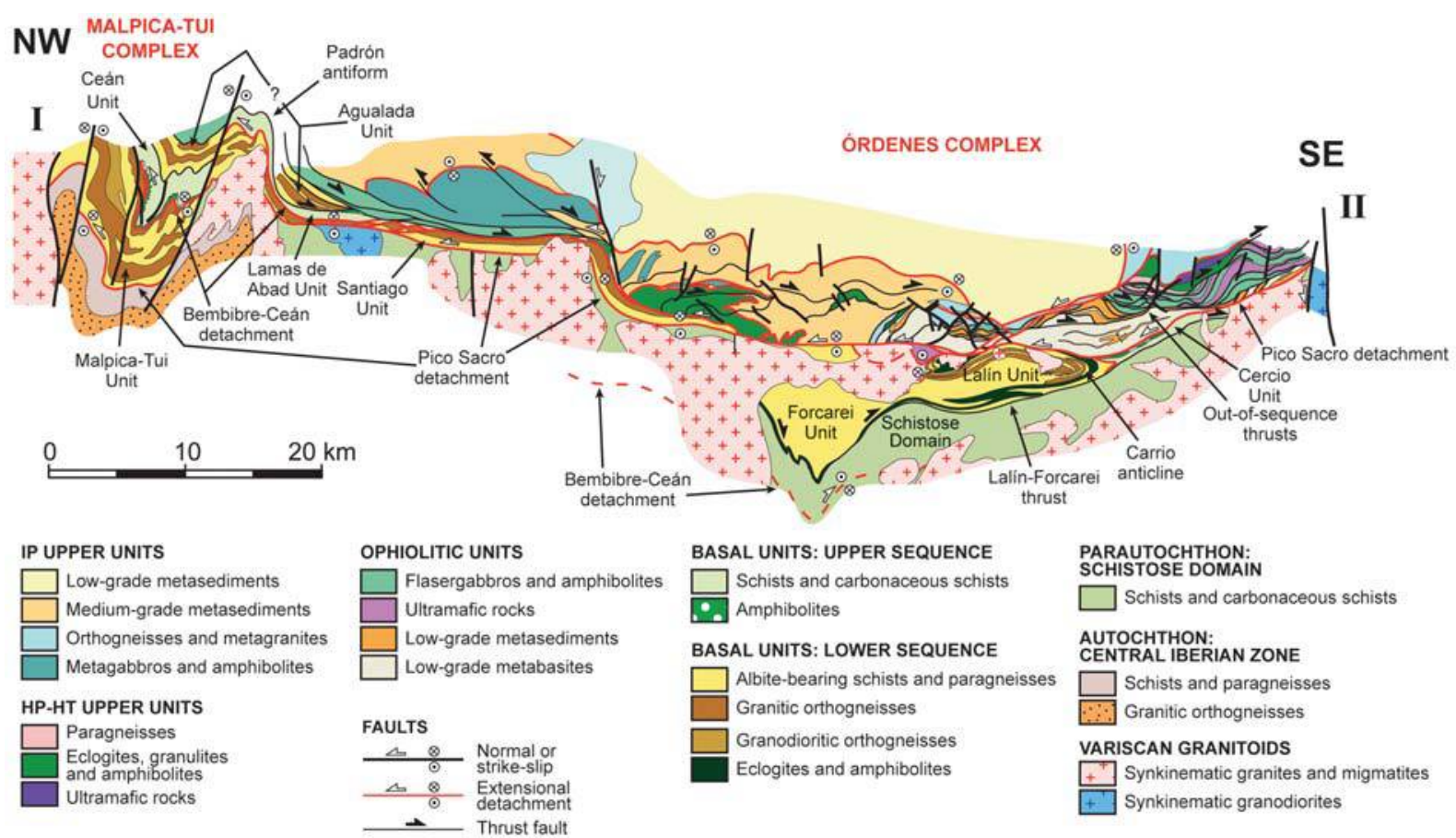

Figure 3. Geological section across the Malpica-Tui and Órdenes allochthonous complexes. For location of section, see figure 2.

Rheic Ocean (Díaz García et al. 1999; Arenas et al. 2007; Sánchez Martínez et al. 2009). The basal units represent the most external part of the Gondwana margin (Díez Fernández et al. 2010), which was subducted beneath Laurussia at the onset of the Variscan collision (Arenas et al. 1995, 1997; Abati et al. 2010; Díez Fernández et al. 2012b) and exhumed by crustal-scale thrusting accompanied by recumbent folding and tectonic denudation (Martínez Catalán et al. 1996; Díez Fernández and Martínez Catalán 2009; Díez Fernández et al. 2011).

The allochthonous pile was emplaced on top of an imbricate thrust sheet known as the Schistose Domain (Martínez Catalán et al. 1996), which occupies an intermediate position in the regional structural pile, separating the allochthonous complexes from the autochthonous Central Iberian Zone. In the Variscan Orogeny, crustal thickening was followed by thermal relaxation, triggering viscous flow that accommodated gravitational extension of the collisional belt (Martínez Catalán et al. 2002, 2009). Extension was followed by strike-slip tectonics, with associated along-strike shearing, upright folding, and subvertical faulting.

\section{Tectonostratigraphic Framework}

Gravitational extension affected the whole tectonostratigraphic pile described above, of which the basal units of the allochthonous complexes, the parautochthonous Schistose Domain and the autochthonous Central Iberian Zone-exposed in the borders and core of the Padrón dome (fig. 2)-are the focus of this work. Extensive Variscan magmatism (migmatites and granitoids) hides the boundary between the two lower members, which in what follows will be grouped into a single unit, referred to as the relative autochthon.

Two stratigraphic sequences can be recognized in the basal units (Díez Fernández et al. 2010). Variscan deformation and metamorphism transformed them into a layered tectonostratigraphy, which consists of albite-bearing schists and paragneisses that alternate with massifs of Cambrian and Ordovician granitic orthogneisses in the lower sequence (Abati et al. 2010; Díez Fernández et al. 2012a) and with lenses of metabasites in the upper sequence (figs. 2, 3). The relative autochthon includes schists on top, migmatitic paragneisses in an intermediate position, and glandular orthogneisses at the bottom (e.g., fig. 3).

\section{Tectonometamorphic Framework of the Basal Units}

The subduction-exhumation process individualized the two tectonostratigraphic sequences into 
two tectonic sheets, the upper and the lower sheet, respectively (figs. 2, 3; Díez Fernández et al. 2011). They are preserved along the allochthonous complexes as an ensemble of units that share a common tectonic record developed under different metamorphic conditions. The differences lie on the $P T$ conditions reached during the subduction, their relative position during the exhumation, and the crustal level they occupied during the subsequent gravitational reequilibration. Five main phases of deformation can be recognized.

First Phase $\left(D_{1}\right)$ : Continental Subduction. Fabric relicts $\left(S_{1}\right)$ enclosed within porphyroblasts grown during exhumation $\left(\mathrm{S}_{2}\right)$ and non- or poorly retrogressed lenses of high-pressure rocks evidence the initial continental subduction. The metamorphic conditions range from blueschist to eclogite facies (Arenas et al. 1995; Rubio Pascual et al. 2002; Rodríguez et al. 2003; López-Carmona et al. 2010). No relicts of a high-pressure fabric have been identified in the uppermost levels of the upper sheet, where the temperature related to the subduction event was probably the lowest among the basal units.

Second Phase $\left(D_{2}\right)$ : Exhumation Driven by Fold Nappe Structures. The early exhumation took place under heterogeneous ductile shearing. This phase is responsible for the regional foliation $\left(\mathrm{S}_{2}\right)$ and lineation (Martínez Catalán et al. 1996; Llana-Fúnez and Marcos 2002; Díez Fernández and Martínez Catalán 2009). $S_{2}$ formed in relation to the nucleation, propagation, and amplification of large recumbent folds and ductile thrusts under amphibolite/greenschist facies conditions (Díez Fernández et al. 2011). In the metasedimentary rocks, $S_{2}$ is a schistosity defined by statistically oriented mica, quartz, albite porphyroblasts, and garnet, which can be accompanied by rare staurolite or by chloritoid in the upper sheet. The pre-Variscan granitic rocks show a subconcordant $S_{2}$ gneissic foliation and mineral lineation, formed by the segregation of mineral phases into quartz-feldspathic and ferromagnesian layers.

Third Phase $\left(D_{3}\right)$ : Out-of-Sequence Thrust System. The obduction of the ophiolitic and upper units of the allochthonous complexes over the basal units formed an imbricate family of discrete thrust faults postdating the first stage of exhumation (Martínez Catalán et al. 2002).

Fourth Phase $\left(D_{4}\right)$ : Extensional Collapse. The basal units were affected by ductile to ductile-brittle extensional shearing afterward. In the Malpica-Tui Complex and the western half of the Órdenes Complex, the metasedimentary rocks at the basal levels of the lower sheet developed a low-pressure/hightemperature schistosity/gneissic banding $\left(\mathrm{S}_{4}\right)$.
There, $\mathrm{S}_{4}$ is composed of quartz + white mica + biotite \pm andalusite \pm cordierite \pm sillimanite \pm albite \pm tourmaline. In the upper sheet, retrogression of pre- $\mathrm{S}_{4}$ fabrics occurred all around the Padrón dome, with associated development of a penetrative low-pressure/low-temperature $\mathrm{S}_{4}$ schistosity composed of quartz + white mica + chlorite \pm biotite \pm opaque minerals in the metasedimentary rocks and albite + epidote + actinolite-tremolite + chlorite \pm quartz \pm biotite \pm titanite \pm pyrite in the mafic rocks.

Fifth Phase $\left(D_{5}\right)$ : Strike-Slip Tectonics. All the previous fabrics were bent into open to tight upright folds and cut by transcurrent shear bands. $\mathrm{D}_{5}$ retrogression occurs in low-grade (chlorite-rich) strikeslip shear zones and in subvertical crenulation cleavage $\left(\mathrm{S}_{5}\right.$, greenschist facies), which occur together with subhorizontal stretching and crenulation lineations $\left(\mathrm{L}_{5}\right)$ anywhere across the MalpicaTui Complex (Díez Fernández 2011).

\section{Tectonometamorphic Framework of the Relative Autochthon}

Emplacement of the Allochthonous Complexes $\left(D_{2}\right.$, $D_{3}$ ?). No evidence of a high-pressure metamorphic gradient has been found in the relative autochthon, which escaped subduction. The first deformative fabric recognized here is a tectonic banding preserved either as a crenulated foliation or as an internal schistosity in andalusite porphyroblasts. It is a greenschist to amphibolite facies fabric composed of quartz + white mica + biotite + plagioclase + garnet \pm staurolite \pm tourmaline \pm opaque minerals. The lack of high-pressure relicts suggests correlation with the exhumation and emplacement of the basal units onto the relative autochthon.

Staurolite mainly occurs toward the intermediate and lower structural sections and sets the maximum temperature of these levels during deformation to a range of $550^{\circ}-620^{\circ} \mathrm{C}$ (Powell and Holland 1990). The pressure can be indirectly set by using the tectonometamorphic evolution of the upper sheet of the basal units to a minimum value of $7 \mathrm{kbar}$ (Arenas et al. 1995; López-Carmona et al. 2010). This value is probably an underestimation because the minimum thickness of the lower sheet has not been taken into account (10-12 km; Díez Fernández et al. 2011).

There are no data on the role of the out-ofsequence thrust system $\left(D_{3}\right)$ in the relative autochthon.

Extensional Collapse. $S_{4}$ in the relative autochthon correlates with the $S_{4}$ described for the basal 
units. In the metasedimentary rocks, $\mathrm{S}_{4}$ includes quartz + biotite + white mica + plagioclase \pm andalusite \pm sillimanite \pm tourmaline \pm opaque minerals, whereas in the glandular orthogneisses, it is defined by quartz-feldspathic and mica-rich layers (rare garnet). $S_{4}$ blurs most of the previous record and ranges between a crenulation cleavage and a tectonic/gneissic banding. It progressively turns into a migmatitic layering toward the lower structural levels, where granitic leucosomes composed of quartz, feldspar, and plagioclase are interbedded with restitic patches of sillimanite, quartz, biotite, garnet, staurolite, and opaque minerals.

Lenses of synkinematic leucogranites abound in the relative autochthon (scarce patches in the basal units), increasing their abundance and size toward the lower structural levels. Massifs of Variscan granitoids also occur toward the lower structural levels. Both the massifs and lenses show parallelism with the $\mathrm{S}_{4}$ tectonic fabric. The morphology of these massifs is tabular (sheetlike) in the upper parts, as revealed by the geometry of their contacts when they are folded by major $\mathrm{D}_{5}$ upright structures. Their shape changes to irregular and massive downward, where they define the granitic core of the Padrón dome. The synkinematic character of the granitoids is indicated by the structural parallelism between them and the fabric in the relative autochthon, as well as by the correlation of synkinematic metamorphism in the host rocks and the $P T$ conditions of magma emplacement (Paterson et al. 1989).

The development of migmatites, reinjected local melts, and sillimanite-accompanied by the development of an andalusite-bearing foliation affecting these melts-suggests a prograde evolution within a decompressive metamorphic path, which cuts the curves of melting at medium-pressure conditions to reach the andalusite stability field. Syn$\mathrm{S}_{4}$ andalusite in metasedimentary rocks points to $P \leq 4.5$ kbar (Holdaway 1971). The previous deformation phase developed under $P>7 \mathrm{kbar}$, which points to $8 \mathrm{~km}$ of minimum crustal thinning during $\mathrm{D}_{4}$. But the current thickness of the $\mathrm{D}_{2}$ structure preserved in the overlying basal units is $15 \mathrm{~km}$ (Díez Fernández et al. 2011), and the minimum estimated pressure for its upper section is about 6 kbar, actually implying $21 \mathrm{~km}$ of minimum crustal thinning related to $\mathrm{D}_{4}$ extensional flow.

Strike-Slip Tectonics. $\quad \mathrm{D}_{5}$ deformation shows similar features as in the basal units.

\section{The Macrostructural Framework}

A major ductile reverse fault, the Fervenza thrust, followed by the propagation toward the foreland of a train of recumbent folds drove the early exhumation of the basal units (fig. $4 a$; Díez Fernández et al. 2011). $\mathrm{D}_{2}$ nappe tectonics culminated with the Lalín-Forcarei thrust, which was followed by a set of out-of-sequence thrusts $\left(\mathrm{D}_{3} ;\right.$ fig. $\left.4 b\right)$.

Ductile and ductile-brittle structures developed during the gravitational collapse in the Padrón migmatitic dome. The first, represented by $\mathrm{S}_{4}$, developed in relation with the latter, a set of strongly subtractive extensional detachments bounding the main domains mentioned in this article (figs. 2, 3). The Bembibre-Ceán detachment marks the contact between the two tectonic sheets of the basal units. The Pico Sacro detachment affects the upper, ophiolitic, and basal units, putting them into contact with the relative autochthon in the northern half of the allochthonous complexes. The RedondelaBeariz detachment separates the basal units from the relative autochthon in the southern half of the allochthonous complexes.

\section{The Bembibre-Ceán Detachment}

The Bembibre-Ceán detachment is defined by an ultramylonite several decimeters to up to $2 \mathrm{~m}$ thick, mainly developed in the orthogneisses of the lower sheet of the basal units. It consists of millimeter-scale alternations of disrupted quartz ribbons, microgranoblastic aggregates of plagioclase, chlorite, white mica, $S_{2}$ white mica porphyroclasts with strong undulate extinction and kink-bands, and reoriented relicts of retrogressed $\mathrm{S}_{2}$ garnet and clinozoisite (chlorite, white mica, and quartz). The quartz-feldspathic fraction concentrated most of the deformation, and a set of SC and $\mathrm{SC}^{\prime}$ discrete ultramylonitic shears bounds $\mathrm{S}_{2}$ white mica porphyroclasts and other domains affected by a less intense mylonitic foliation. These bands surround $\mathrm{K}$-feldspar phenocrysts, which have been strongly deformed and recrystallized and show intense saussuritization.

The deformation gradient related to this contact decreases both upward and downward, with secondary ultramylonitic shear zones occurring several meters above and below the main one. They are accompanied by NNW- and NNE-verging overturned folds developed on $\mathrm{S}_{2}$ and may also affect the extensional foliation $S_{4}$ (intrafolial folds). Toward the top, the mylonitic shear zones are progressively replaced by widely developed $S_{4}$, which is the main foliation in the upper sheet all around the Padrón dome. A map-scale $\mathrm{D}_{4}$ phyllonite occurs in an intermediate position within the upper sheet in the Ceán Unit (fig. 5). Structural parallelism between shear planes, similar kinematics, and metamorphic 

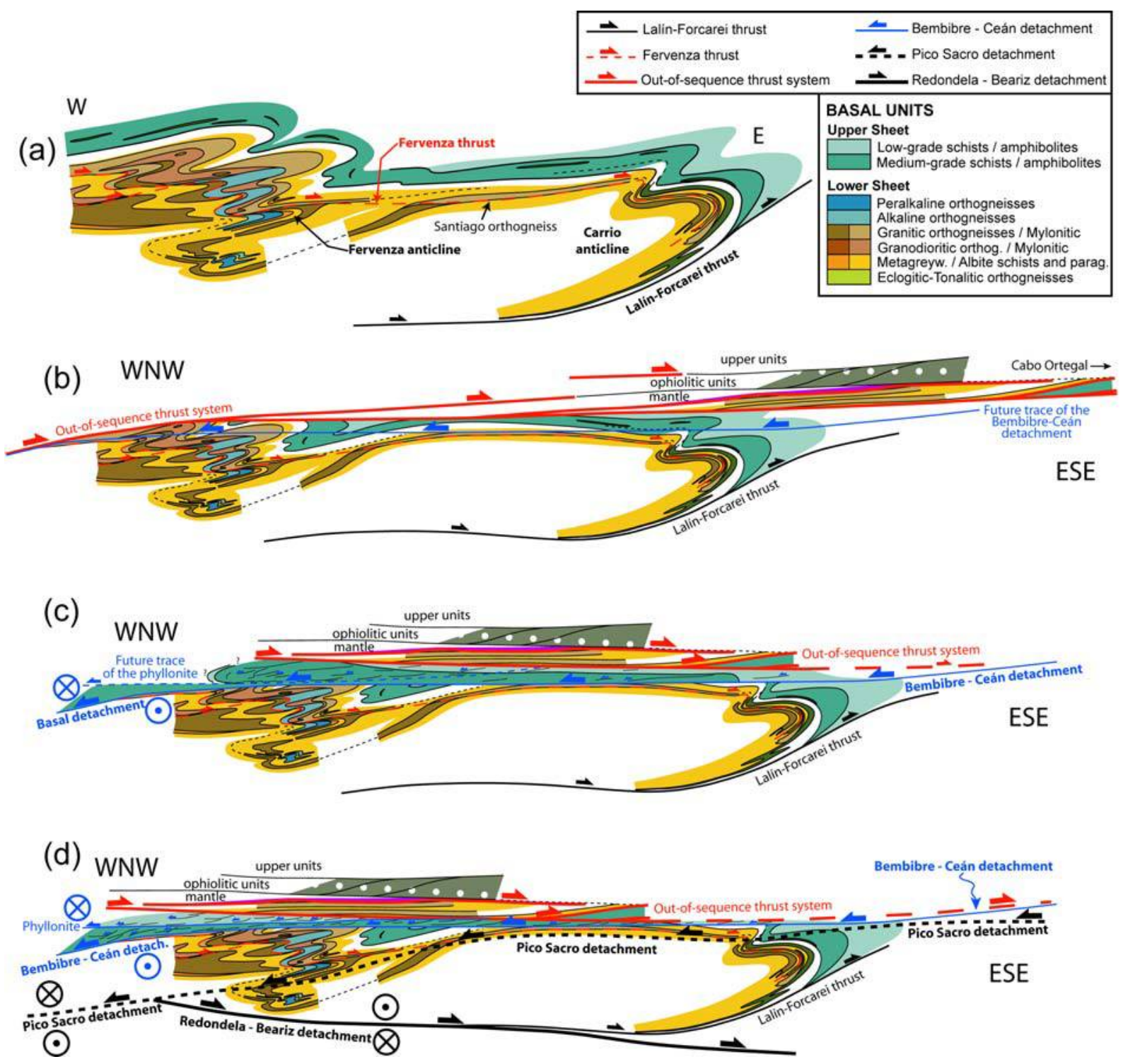

Figure 4. Evolution of the exhumation of the basal units in western Galicia. $a$, Macrostructure after $\mathrm{D}_{2}$ exhumation of the basal units by fold nappe structures (Díez Fernández et al. 2011). b, Out-of-sequence thrust system responsible for the exhumation of the overlying ophiolitic and upper allochthonous units. Notice the future trace of the BembibreCeán detachment, whose development is shown in two stages $(c, d)$. The lower extensional system, formed by the Pico Sacro and Redondela-Beariz detachments, is shown in $d$. The sections are oblique to the direction of motion of the detachments to show the structural relationships with the $\mathrm{D}_{2}$ train of recumbent folds.

affinity suggest that $\mathrm{S}_{4}$ and the mylonites/phyllonites represent the transition from ductile to ductilebrittle deformation conditions of a single tectonic event, under progressively colder metamorphic conditions.

Kinematic criteria in $\mathrm{D}_{4}$ mylonitic fabrics in the granitic orthogneisses include SC and several generations of $\mathrm{C}^{\prime}$ shear bands, $\sigma$ structures in quartz, feldspar and polymineral aggregates, mica fish in white mica, and asymmetric pressure shadows in feldspar porphyroclasts. All of them plus the crys- tallographic asymmetry of subgrains in quartz ribbons, the asymmetry of intrafoliar folds, and the attitude of the stretching lineation $\left(\mathrm{L}_{4}\right)$ indicate topto-the-N-NW $\mathrm{D}_{4}$ shearing in the Ceán Unit (fig. 6a). This agrees with $\mathrm{D}_{4}$ flow in the northern section of the Órdenes Complex (fig. 6b) and matches that of its southern sections (Gómez Barreiro et al. 2010).

There are stretching lineations associated to $\mathrm{S}_{4}$ that do not match the top-to-the-N-NW shearing of the detachment system at the fault zone. Their 


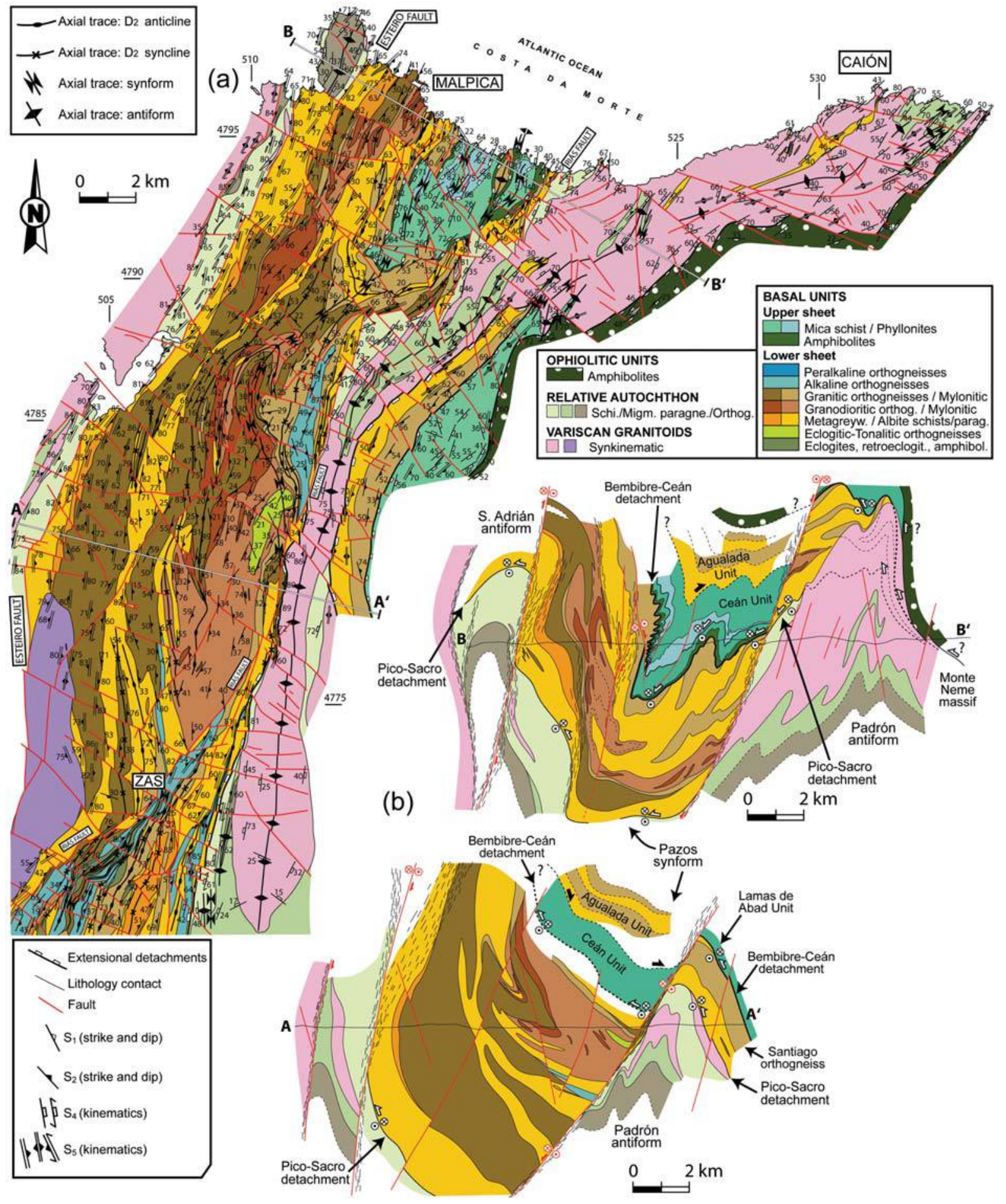

Figure 5. Geological map $(a)$ and two cross sections $(b)$ of the northern part of the Malpica-Tui Complex and the NW of the Órdenes Complex. UTM coordinates. After Díez Fernández et al. (2011). 


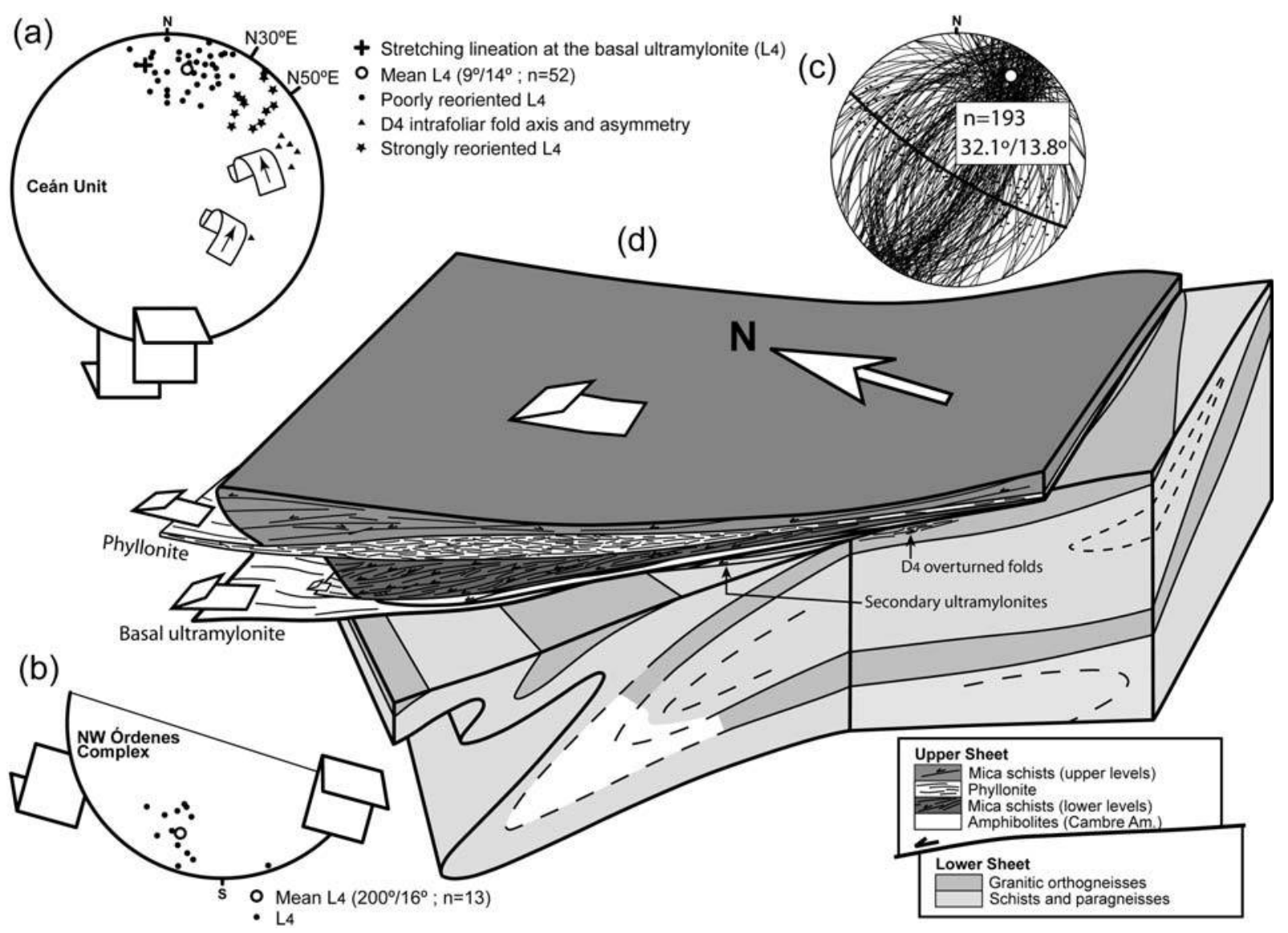

Figure 6. $a$, Stereographic plot of $\mathrm{D}_{4}$ stretching lineations and intrafoliar fold axes (with asymmetry) in the Ceán Unit. $b$, Stereographic plot of $\mathrm{D}_{4}$ stretching lineations of the northern sections of the Lamas de Abad Unit (NW Ordenes Complex). c, Stereographic plot of the main foliation $\left(\mathrm{S}_{4}\right)$ showing the deduced statistical orientation of $\mathrm{D}_{5}$ fold axis (white dot) in the Ceán Unit. The plot includes the planes (large circles), pole to the planes (black dots), and cylindrical best fit (thick large circle). $d$, Structural sketch of the contact between the Ceán Unit (upper sheet) and the Malpica-Tui Unit (lower sheet) after restoring upright $\mathrm{D}_{5}$ folding. A color version of this figure is available in the online edition or from the Journal of Geology office.

trends span the range $30^{\circ} \mathrm{N}-50^{\circ} \mathrm{N}$, and they occur in locations showing intense $\mathrm{D}_{5}$ upright folding. $\mathrm{D}_{5}$ fold axes depict the same trend interval (fig. $6 c$ ), so the anomalous orientation of $\mathrm{L}_{4}$ there is likely related to clockwise reorientation by $\mathrm{D}_{5}$ folding and shearing of a previous NNW-SSE stretching lineation. Similar geometrical relationships can be seen in the NW section of the Órdenes Complex (fig. $6 b)$.

The Bembibre-Ceán detachment cuts the $\mathrm{D}_{2}$ recumbent folds of the lower sheet exposed in the Malpica-Tui Unit (fig. 6d) and runs along the normal limb of the Carrio anticline (figs. 3, 5). The recumbent folds truncated toward the $\mathrm{N}$ reappear southward, while the Bembibre-Ceán detachment does not, which, together with its kinematics, in- dicates that it was a $\mathrm{N}$-dipping low-angle normal fault.

In the Ceán Unit, syn- $\mathrm{D}_{1}$ and $\mathrm{D}_{2}$ metamorphic records presently exhibit a normal but condensed zoning (López-Carmona et al. 2010), and the same holds for the upper sheet of the basal units cropping out in different parts of the Órdenes Complex (Gómez Barreiro et al. 2010) and in similar relicts preserved in the Cabo Ortegal Complex (Arenas 1988).

The out-of-sequence thrust system was truncated by the Bembibre-Ceán detachment and transported its hanging wall toward the NNW (fig. $4 b$ ), together with pieces of the upper sheet preserved in the Ceán Unit and W of the Órdenes Complex. The Cercio Unit (figs. 2, 3) is comparable to the upper part of the Ceán Unit. Both were probably 
close before $\mathrm{D}_{4}$ extension, so that the base of the detachment can be traced from above the Cercio Unit, probably at its footwall, to the base of Ceán (fig. 4c), setting the offset along strike in several tens of kilometers (fig. $4 d$ ).

\section{The Basal Detachment System of the Allochthonous Complexes}

The Pico Sacro and Redondela-Beariz detachments are a set of paired low-angle extensional faults (figs. 2, 3). No exposures of their fault zones have been found around the Malpica-Tui Complex, but field data suggest that they are high- to ultrahigh-strain shear zones no thicker than $10 \mathrm{~m}$ and probably ultramylonitic in nature. The Pico Sacro detachment, as described by Martínez Catalán et al. (2002) in the Órdenes Complex, can be correlated with the base of the northern half of the Malpica-Tui Complex via the Padrón dome (figs. 2, 3, 5). The Redondela-Beariz detachment (figs. 2, 3, 7) extends from the Malpica-Tui to the Ordenes Complex, through the extensional shear zone that affects the Beariz granite (González Cuadra et al. 2006).

The local development of $\mathrm{S}_{4}$ within the MalpicaTui Unit and its extensive development in the relative autochthon outline a heterogeneous asymmetric shear zone (fig. 8). Given the intense grain-size reduction and the development of a penetrative tectonic layering $\left(\mathrm{S}_{4}\right)$, the whole metasedimentary rock sequence of the relative autochthon can be considered as a regional high-strain shear zone. In this crustal section, the extensional flow flattened and stretched medium-size synkinematic granitoids and attenuated the syn- $\mathrm{D}_{4}$ normal metamorphic zonation.

$\mathrm{D}_{4}$ kinematic criteria include $\mathrm{SC}, \mathrm{SC}^{\prime}$, mantle porphyroclasts, mica fish, and asymmetric folds. The shear bands affect both the pre- $\mathrm{D}_{4}$ planar anisotropies (compositional layering and foliations) and the Variscan synkinematic granitoids. The attitude of the stretching lineation $\left(\mathrm{L}_{4}\right)$ provides a good approximation to the extensional flow. It changes from top to the S-SE in the southern half of the Malpica-Tui Complex (fig. 9a) to top-to-the$\mathrm{N}-\mathrm{NNW}$ in its northern half and in the Ordenes Complex (fig. $9 b-9 e$ ) and is related with the opposite motion of the Redondela-Beariz and Pico Sacro detachments, respectively.

The mean attitude of $\mathrm{L}_{4}$ is N-S, ranging from NWSE to NE-SW (fig. 9). $\mathrm{D}_{5}$ structures (fold axes and lineations) are oblique to $\mathrm{L}_{4}$, usually showing azimuths clockwise in relation to its trend (fig. 9). This fact is important because $D_{5}$ strike-slip tectonics controls the structural patterns at the boundaries of the Malpica-Tui Complex, right where the fabrics related to the basal extensional system are cropping out today.

$\mathrm{L}_{4}$ was reoriented by $\mathrm{D}_{5}$ strike-slip shear zones and, in most cases, would have rotated clockwise during $\mathrm{D}_{5}$ dextral shearing. The initial maximum stretching direction in a transpressional shear zone ranges between $25^{\circ}$ and $45^{\circ}$ with respect to the shear planes (Sanderson and Marchini 1984; Tikoff and Peterson 1998), evolving to smaller values as deformation progresses. Such initial orientation constrains the original angle of $\mathrm{L}_{4}$ to have been larger than the actual value for $L_{5}$ and sets the tectonic flow related to the $\mathrm{D}_{4}$ basal extensional system at high angles to the trend of the chain. This flow fits the mean trend preserved in the poorly or nonreoriented domains (fig. 9d) and is similar to that preserved in the Órdenes Complex (Gómez Barreiro et al. 2010).

In the E-W direction, the detachments cut the $\mathrm{D}_{2}$ macrostructure just like shown in figure $4 d$. The same occurs in a longitudinal section, where it can be deduced that the greater subtraction at the base of the Malpica-Tui Complex occurred slightly to the south of its central part and that the dip of the $\mathrm{D}_{2}$ axial surfaces was gentler than the basal detachments, which would dip to the $\mathrm{N}$ in the central and northern half of the Malpica-Tui Complex (Pico Sacro) and to the $S$ in its southern section (Redondela-Beariz). The change in the extensional flow and dip of detachments coincides with a change of the plunge of the synform hosting the Malpica-Tui Complex (fig. 2). Both domains are separated by a culmination whose open character and the absence of associated cleavage suggest an original link to the extensional event, just like most of the upright open folds affecting the allochthonous complexes of NW Iberia.

The glandular orthogneisses of the relative autochthon crop out in the core of the two major antiforms flanking the Malpica-Tui Complex: the Padrón and San Adrián antiforms (e.g., fig. 5b). The orthogneisses, normally occupying deep positions in the relative autochthon, occur here very close to both sides of the complex, supporting the symmetry deduced from the condensed, normal metamorphic zoning in the relative autochthon. Llana Fúnez (2001) described an asymmetric distribution of the metasedimentary rock series in the relative autochthon (fig. 10a), which he explained by late Variscan strike-slip tectonics (Llana-Fúnez and Marcos 2001). Although transcurrence was important, the symmetry found here indicates that thrust and extensional tectonics played the most significant role, as suggested in figure $10 b$ and $10 c$. 


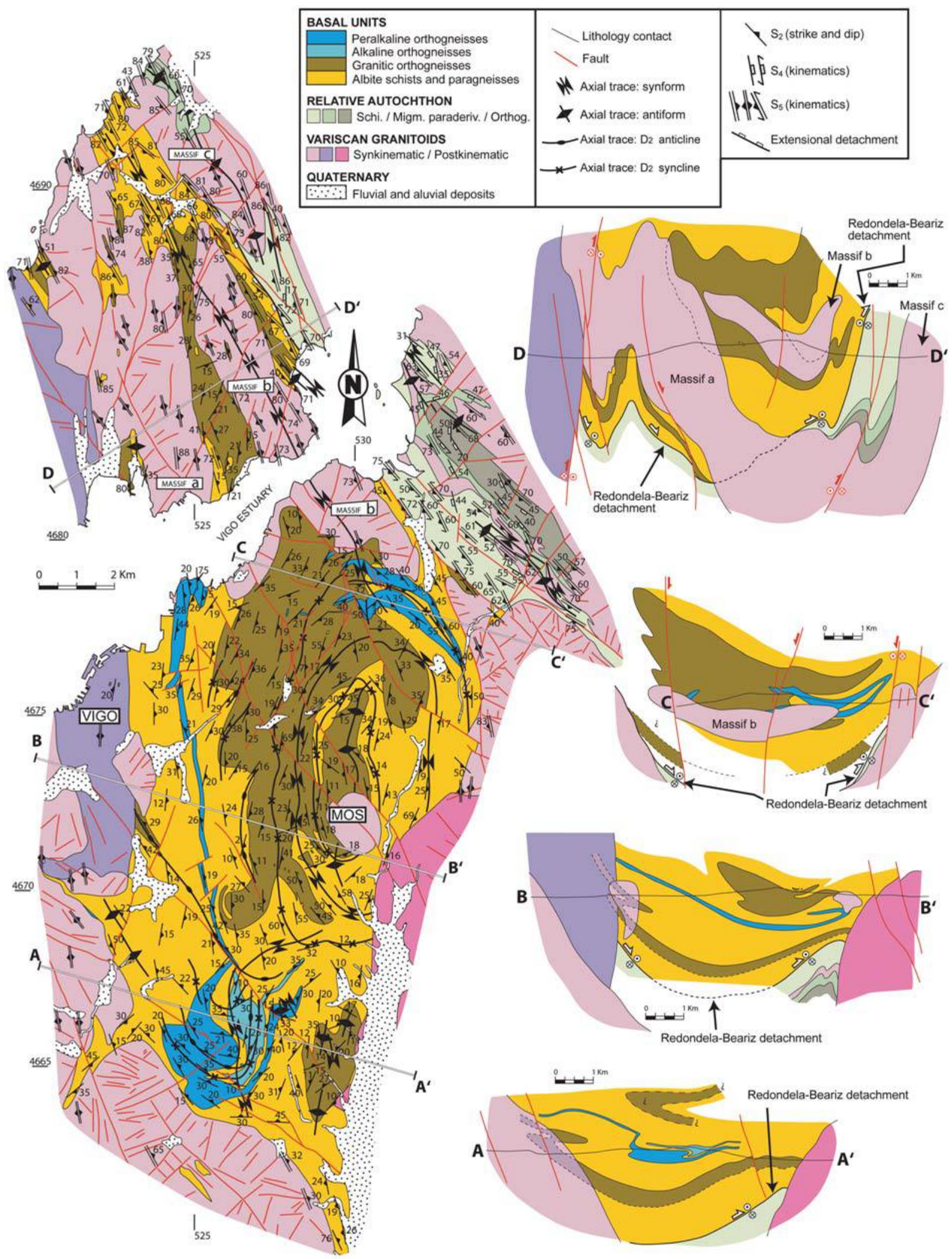

Figure 7. Geological map (left) and cross sections (right) of the southern part of the Malpica-Tui Complex. UTM coordinates. After Díez Fernández and Martínez Catalán (2009). 

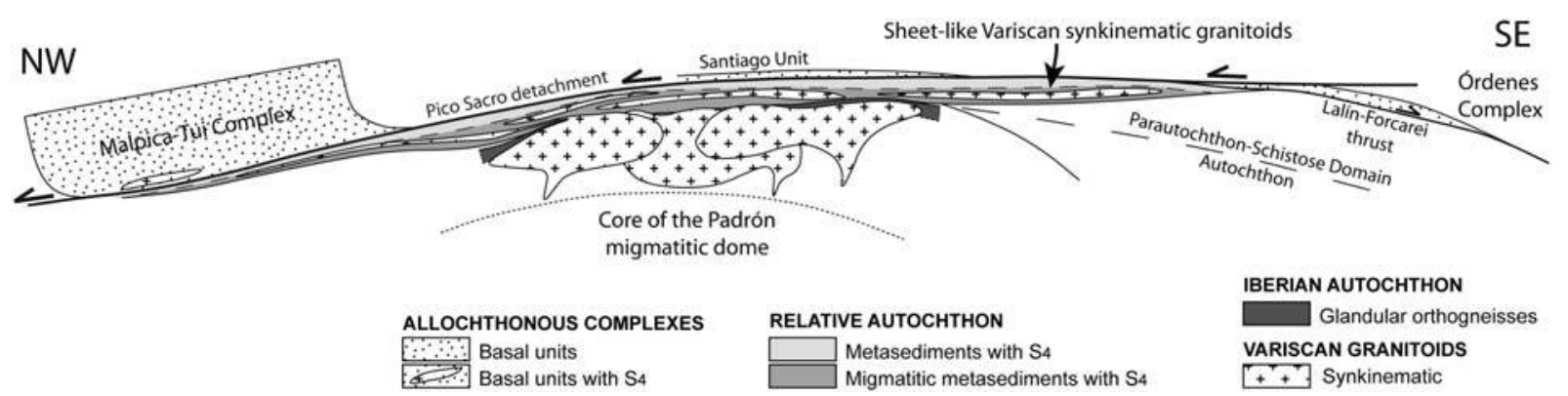

Figure 8. Two-dimensional model of the extensional heterogeneous asymmetric shear zone developed at the base of the basal allochthonous units (Pico Sacro detachment). The ductile tectonic flow is channeled through the footwall of low-angle faults, while the hanging wall remains as a relatively passive domain. A color version of this figure is available in the online edition or from the Journal of Geology office.

Minimum $\mathrm{D}_{4}$ crustal thinning within the relative autochthon can be better estimated where $D_{5}$ wrench tectonics is less important. In the eastern half of the Malpica-Tui Complex, the metasedimentary rock pile above the glandular orthogneisses is about $2000 \mathrm{~m}$ thick, less than half the thickness of the Schistose Domain, which is estimated at 5000-5500 m (Marquínez García 1984). Moreover, the orthogneisses normally occur hundreds to thousand meters deep in the Central Iberian Zone sedimentary pile. Thus, the attenuation of the tectonostratigraphic record is in agreement with the values estimated from the metamorphic data $(>21 \mathrm{~km})$.

\section{Discussion}

Three extensional faults dismembered the $\mathrm{D}_{2}$ macrostructure of the basal units around the Padrón dome: Redondela-Beariz, Pico Sacro, and BembibreCeán (fig. 11a), the two first forming a divergent system of conjugated shear zones. On the basis of the estimated age of the Lalín-Forcarei thrust (around 340 Ma; Martínez Catalán et al. 1996; Dallmeyer et al. 1997) and on the age of synkinematic leucogranites intruding the relative autochthon (Rodríguez et al. 2003), their motion took place between 340 and $317 \pm 3 \mathrm{Ma}$, with the BembibreCeán detachment being older than the Pico Sacro detachment (Gómez Barreiro 2007; Gómez Barreiro et al. 2010).

Extensional detachments are very efficient mechanisms to lessen gravitational disequilibrium, since they provide mass transfers that reduce the gradients of potential energy (England 1982; Molnar and Chen 1982, 1983; Coney and Harms 1984; McClay et al. 1986; Dewey 1988; Ménard and Molnar 1988; Molnar and Lyon Caen 1988; England and Houseman 1989). Such property explains that the dip direction of detachments is commonly parallel to the extensional flow.

Faults related with extensional tectonics and crustal thinning are common structures related to the gravitational collapse of a thickened continental crust (Coney and Harms 1984; Platt 1986; Malavieille 1987; Dewey 1988; Lister and Davis 1989; Platt and England 1994; Ruppel 1995; Rey et al. 2001). The faults are synchronous with flat-lying ductile shearing, attenuate previous and coeval tectonometamorphic gradients, and are associated with low-pressure/high-temperature metamorphism and with partial melting of deep structural levels, which gives rise to the formation of migmatitic domes. In the Iberian Massif, extensional detachments follow the maximum crustal thickening. The Lalín-Forcarei thrust and the out-ofsequence thrust system transferred the peri-Gondwanan terranes to the internal parts of the Gondwana mainland, which-together with previous thickening of the autochthon-caused the thermal disequilibrium of the orogenic belt (Alcock et al. 2009). The thermal reequilibration favored the partial melting of fertile crustal layers as first response, causing the destabilization of the rheological profile of the crust (Ord and Hobbs 1989; Vanderhaeghe and Teyssier 1997, 2001) and the loss of the internal cohesion of the orogen (fig. 11b).

The extensional collapse in NW Iberia fits the fixed-boundary collapse described by Rey et al. (2001). In our case, the activation of extensional detachments accounts for the upper crustal tectonic denudation and crustal attenuation above the Padrón migmatitic dome (e.g., Brun and Van Den Driessche 1994). The distributed vertical flattening represents the lower crustal flow, while the subsequent doming shows the contribution of the diapiric flow to the process (Brun et al. 1981; Bouhallier et al. 1995; Whitney et al. 2004; Yin 2004). The 

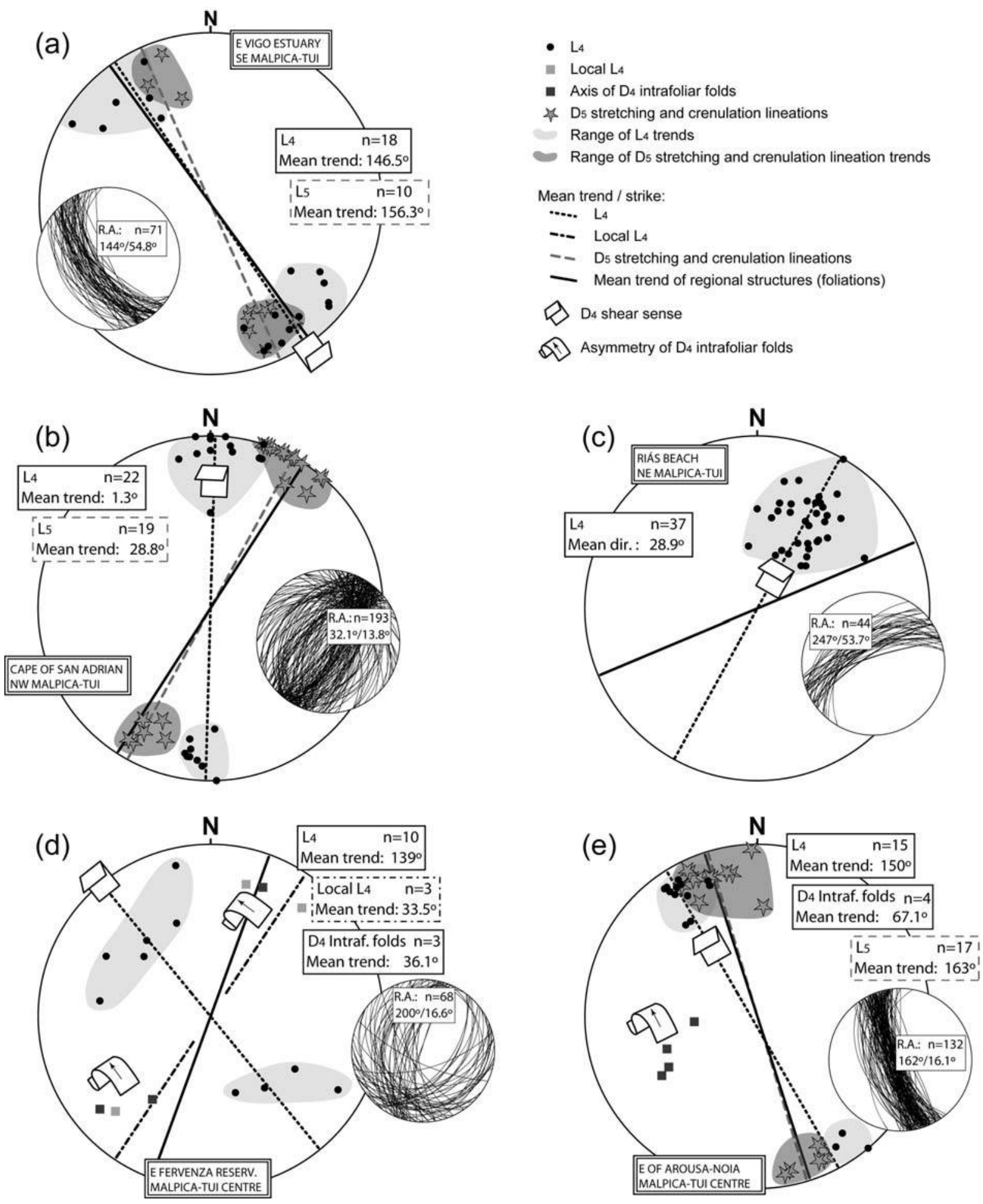

Figure 9. Stereoplots of $\mathrm{D}_{4}$ stretching lineations (with kinematics) and intrafoliar folds (with asymmetry) versus $\mathrm{D}_{5}$ crenulation lineations and mean strike of regional foliation in the relative autochthon (small plots) for the RedondelaBeariz $(a)$ and Pico Sacro $(b-e)$ detachments. $a$, S of Malpica-Tui Complex. $b$, NW of Malpica-Tui Complex (Cape San Adrián). c, NE of Malpica-Tui Complex (Riás Beach). d, NE of Fervenza reservoir (core of the Padrón dome).e, Central section of the Malpica-Tui Complex ( $\mathrm{N}$ of the Arousa estuary). $\mathrm{RA}$, relative autochthon; $\mathrm{n}$, number of data locations. The symbols show the mean trend of several measurements in a single location. A color version of this figure is available in the online edition or from the Journal of Geology office. 


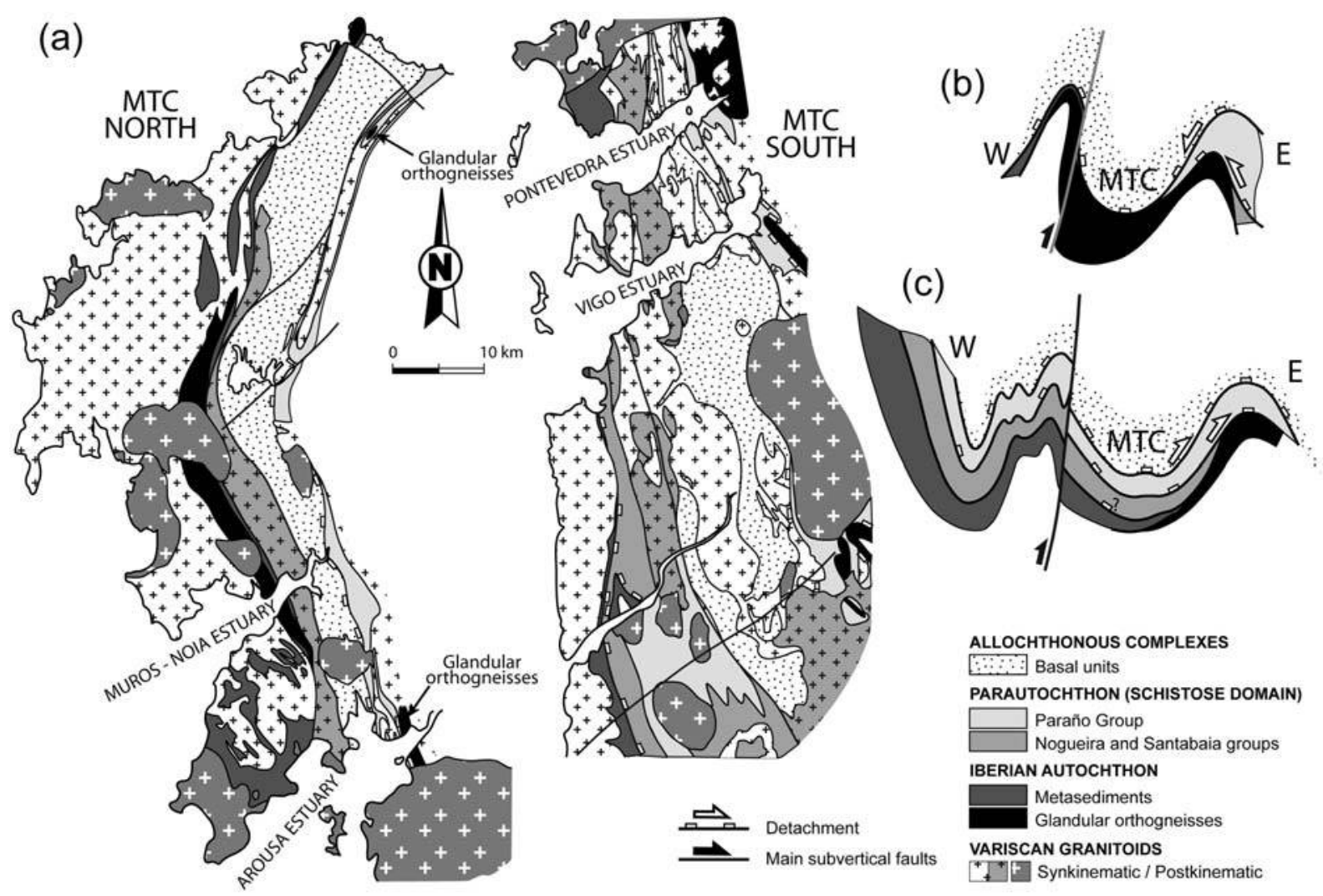

Figure 10. $a$, Geological sketch showing the distribution of the basal allochthonous units, Schistose Domain, and Central Iberian Zone autochthon around the Malpica-Tui Complex (modified from Llana Fúnez 2001). Two synthetic cross sections of its northern $(b)$ and southern $(c)$ parts are shown to explain such a distribution by $\mathrm{D}_{4}$ extensional detachments. Variscan granitoids have not been drawn in the cross sections, which are not scaled. A color version of this figure is available in the online edition or from the Journal of Geology office.

detachments are bent into the domes, suggesting that diapiric flow gained importance during the last stages of extension, whereas tectonic denudation played a decisive role during the initial phases.

\section{Tectonic Implications for the Iberian Massif and for Plate Convergence Analysis in Collisional Orogeny}

Late Variscan activity along dextral and sinistral crustal-scale transcurrent shear zones indicates that plate convergence continued after extension (Shelley and Bossiere 2000; Martínez Catalán 2011). Martínez Catalán et al. (2002), Gómez Barreiro (2007), and Gómez Barreiro et al. (2010) suggested that the extensional collapse affecting the allochthonous complexes of NW Iberia developed in a synconvergent setting, as described in other studies (Block and Royden 1990; Buck 1991; Gapais et al. 1992; Wdowinski and Axen 1992; Kaufman and Royden 1994).

In NW Iberia, transport of the Rheic suture zone onto the Gondwana mainland by the out-ofsequence thrusts definitely fused Gondwana and Laurussia, which favored gravity-driven extension, thermal relaxation, and partial melting, thus triggering the development of a low-viscosity channel in the middle/lower crust. NW Iberia forms part of the axial zone of the Variscan belt, where extensive synkinematic magmatism occurs. From a regional point of view, this area represents the decoupling of the extending upper crust from the lower crust (Rey et al. 2001) and a weak crustal section prone to assume significant plate interaction during the late stages of collision. The area was bounded by the two main landmasses involved in the collision (Gondwana and Laurussia), whose extension-free domains would define the boundaries of a virtual along-strike megashear zone (fig. 12a). The development of syn-extensional strike-slip shear zones at the borders or within this domain must not be ruled out (e.g., McFadden et al. 2010). In this scenario, the regional stress field may be deduced from the analysis of the active structures, just like in 

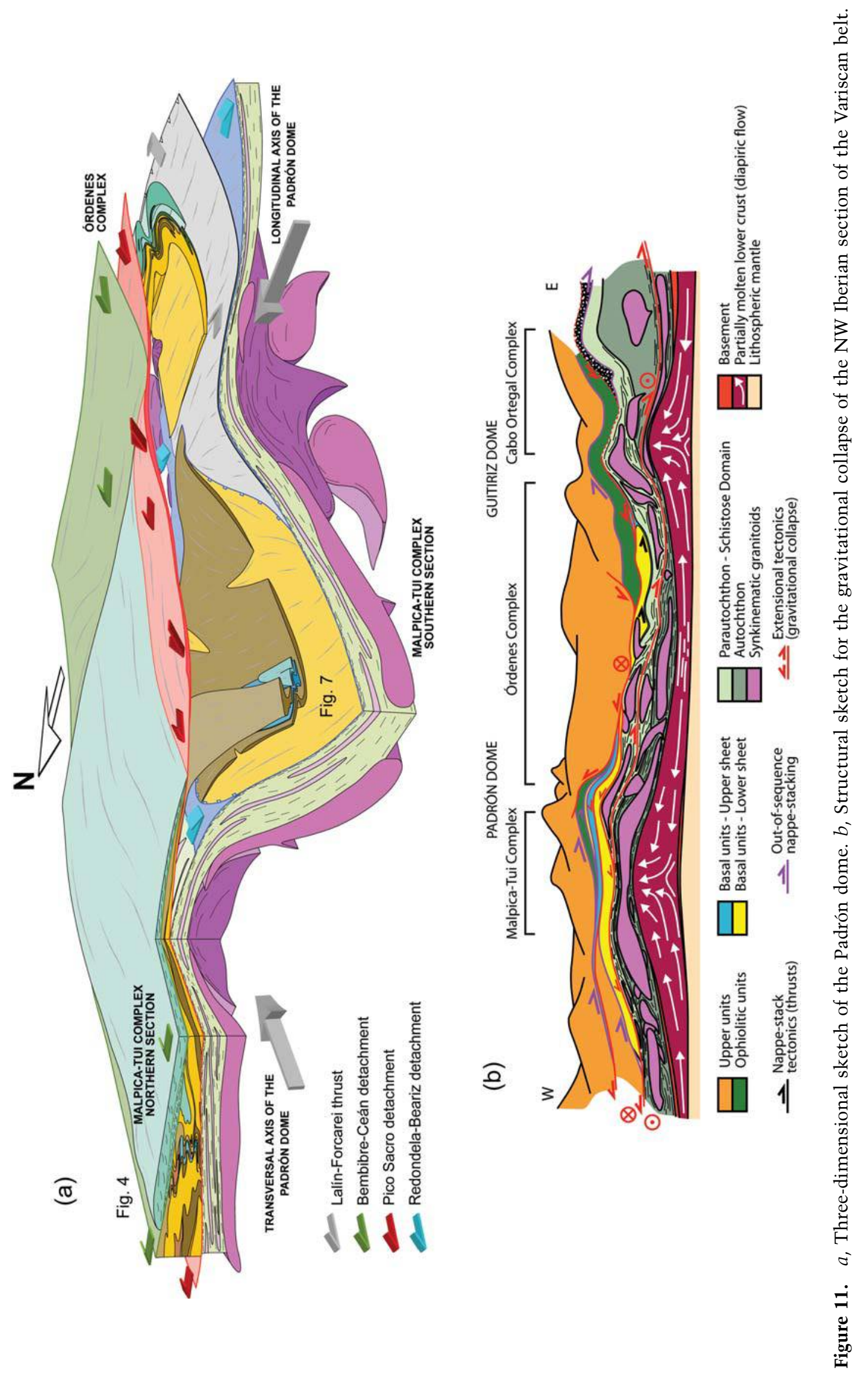


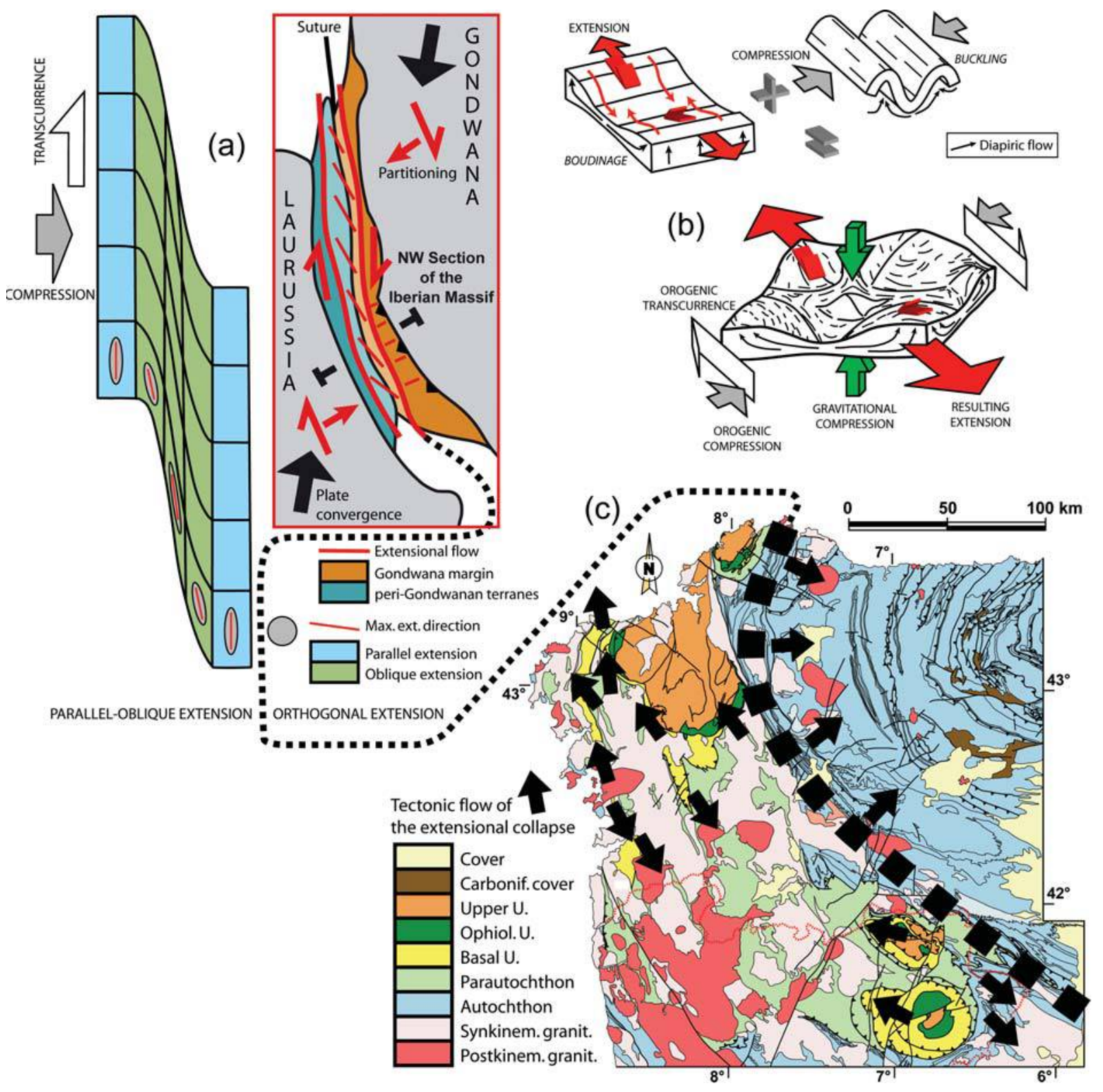

Figure 12. $a$, Dextral transpressive shear zone model showing the directions of maximum stretching (left) and its application to the gravitational collapse of a lineal orogenic belt (the Variscan belt; right). $b$, Model explaining the regional dome and basin structure by interference of buckling folds and crustal thinning and boudinage. Both mechanisms may activate diapiric flow. $c, \mathrm{D}_{4}$ Extensional flow vectors in the NW Iberian Massif. The thick dashed line separates the zones with flow vectors normal to the belt from sections with parallel to oblique extensional flow. Data set built from own and compiled data (references in the text).

any other shear zone, obtaining the relative lateral movements of the bounding blocks (Sanderson and Marchini 1984).

The extensional flow described here and that of other sections of the allochthonous complexes and the Central Iberian Zone (relative autochthon) are characterized by vectors ranging from parallel to oblique, in the latter case with a counterclockwise azimuth in relation to the trend of the orogenic belt, which is mainly marked by the late Variscan folds (Ribeiro et al. 1990; Villar Alonso 1990; Escuder Viruete et al. 1994; Díez Balda et al. 1995; Marques et al. 1996; Escuder Viruete 1999; Martínez Catalán et al. 2002; González Cuadra et al. 2006; Díez Montes 2007; Gómez Barreiro 2007; Gómez Barreiro et al. 2007, 2010; González Cuadra 2007). It is difficult to explain such flow directions by only gravitational gradients in a linear colli- 
sional belt. However, they can be explained if a dextral transpressional regime related to plate convergence was active during the collapse (Sanderson and Marchini 1984; Fossen and Tikoff 1993). The gravitational component will tend to produce extension normal to the chain, the normal component of compression will tend to extend it along strike (e.g., Dewey 1988; England and Houseman 1989; Ratschbacher et al. 1989), and the dextral lateral component would favor oblique maximum elongation and tectonic flow relative to the chain (fig. 12a). The direction of maximum extension for each sector will depend on the relative importance of all these factors, which is determined by the local gravitational gradients and the deformation partitioning related to plate convergence.

Figure $12 b$ shows how the interaction of the proposed mechanisms developed the existing structures and how they fed back to each other through the process (Whitney et al. 2004). Orthogonal compression could have started gravitational instabilities by buckling, which were taken to nucleate diapiric structures. Gravitational compression would have produced boudinage in certain crustal levels, both favoring extensional crustal flow and creating room for it to be channeled. The combination of the two mechanisms would create the characteristic dome and basin structure.

The culmination that separates the southern and northern sections of the Malpica-Tui Complex (fig. 11a) was produced by interference between a N-S synform and an E-W antiform. Divergent extensional flow in this section might have been activated first by N-S crustal boudinage, nucleating the E-W antiform, followed by E-W compression giving rise to the N-S synform. The combination of horizontal shortening and extension with diapiric flow explains the absence of a radial or centrifuge flow pattern and also the fact that the dome bends the vectors of extensional flow. These two features are observed along the axial zones of the Variscan belt, both in the Iberian Massif (this article), the French Massif Central (Malavieille et al. 1990; Lagarde et al. 1994; Ledru et al. 2001; Faure et al. 2009), and the German Variscides (Krohe and Eisbacher 1988; Krohe 1998).

To the east of the Iberian Massif (fig. 12c), gravitational collapse shows a main component of extension normal to the belt (Martínez Catalán et al. 2003). The change in the patterns of extension may be due to the attenuation of the transcurrent convergence toward the foreland, far from the limits of the colliding plates (fig. 12a).

The kinematic model described for NW Iberia can be used as an indirect indicator of the regional stress field during the gravitational collapse of the Variscan belt and could be applied to other collisional orogens. According to it, the extensional collapse would have developed while the convergence had not ended and was accompanied by a dextral component of transcurrence. The regional dome and basin structure formed during the initial extension was subsequently flattened under dominant transpression $\left(\mathrm{D}_{5}\right.$ strike-slip tectonics $)$, when the extensional regime vanished. The two processes, which have been classically reported as different deformation events, were partly coeval (Martínez Catalán et al. 2009) and would have developed different structural styles, according to the rheological state of the crust, but under the same regional stress field: dextral plate convergence.

\section{Conclusions}

The analysis of major extensional structures of a collisional mountain belt can be used to decipher the regional stress field active during its gravitational collapse. Noncoaxial extensional flow provides hints on the sense of relative lateral movements between colliding plates, from which it may be possible to infer the broad vectors of plate convergence. Data provided by this method give information about a restricted time interval in a longterm tectonic evolution, allowing the changes in the plate regime to be detected. However, the method requires thorough tectonometamorphic analysis, since the vectors of extensional flow and its timing must be put in the regional framework. Special attention must be paid to the characterization of major oblique extensional structures, since they represent the pillars of the model.

Two main indicators in the Iberian axial zone of the Variscan belt support dextral plate convergence during its extensional collapse. The extensional flow subparallel to the belt suggests orthogonal plate movement, whereas oblique extension in a counterclockwise azimuth in relation to the trend of the belt points to relative dextral movement between Gondwana and Laurussia during the Middle and Late Mississippian. This setting is compatible with further data from other sections of the Variscan belt (France and Germany), and it likely remained during the Pennsylvanian, as reported by orogen-scale dextral strike-slip shear zones.

\section{A C K N O WLEDGMENTS}

We thank J. Abati for his help during the lab and field work. Constructive reviews by S. T. Johnston and an anonymous reviewer as well as editorial 
work of D. B. Rowley are greatly appreciated. This work was funded by the research projects CGL2004-04306-C02-01 and -02/BTE and CGL2007-65338-C02-01 and -02/BTE of the Direc- ción General de Programas y Transferencia del Conocimiento (Spanish Ministry of Science and Innovation), both cofinanced by the European Funds for Regional Development (FEDER).

\section{REFER E N C ES C I T E D}

Abati, J.; Dunning, G. R.; Arenas, R.; Díaz García, F.; González Cuadra, P.; Martínez Catalán, J. R.; and Andonaegui, P. 1999. Early Ordovician orogenic event in Galicia (NW Spain): evidence from U-Pb ages in the uppermost unit of the Ordenes Complex. Earth Planet. Sci. Lett. 165:213-228.

Abati, J.; Gerdes, A.; Fernández-Suárez, J.; Arenas, R.; Whitehouse, M. J.; and Díez Fernández, R. 2010. Magmatism and early-Variscan continental subduction in the northern Gondwana margin recorded in zircons from the basal units of Galicia, NW Spain. Geol. Soc. Am. Bull. 122:219-235.

Alcock, J. E.; Martínez Catalán, J. R.; Arenas, R.; and Díez Montes, A. 2009. Use of thermal modeling to assess the tectono-metamorphic history of the Lugo and Sanabria gneiss domes, Northwest Iberia. Bull. Soc. Geol. Fr. 180:179-197.

Arenas, R. 1988. Evolución petrológica y geoquímica de la unidad alóctona inferior del complejo metamórfico básico-ultrabásico de Cabo Ortegal (Unidad de Moeche) y del Silúrico parautóctono, Cadena Hercínica Ibérica (NW de España). Corpus Geol. Gall. 4:1-543.

Arenas, R.; Abati, J.; Martínez Catalán, J. R.; Díaz García, F.; and Rubio Pascual, F. J. 1997. P-T evolution of eclogites from the Agualada unit (Ordenes Complex, northwest Iberian Massif, Spain): implications for crustal subduction. Lithos 40:221-242.

Arenas, R.; Martínez Catalán, J. R.; Sánchez Martínez, S.; Fernández-Suárez, J.; Andonaegui, P.; Pearce, J. A.; and Corfú, F. 2007. The Vila de Cruces ophiolite: a remnant of the early Rheic Ocean in the Variscan suture of Galicia (northwest Iberian Massif). J. Geol. 115: 129-148.

Arenas, R.; Rubio Pascual, F. J.; Díaz García, F.; and Martínez Catalán, J. R. 1995. High-pressure micro-inclusions and development of an inverted metamorphic gradient in the Santiago-schists (Órdenes-Complex, NW Iberian Massif, Spain): evidence of subduction and syncollisional decompression. J. Metamorph. Geol. 13:141-164.

Beck, M. E. 1983. On the mechanism of tectonic transport in zones of oblique subduction. Tectonophysics 93:1-11.

Block, L., and Royden, L. H. 1990. Core complex geometries and regional scale flow in the lower crust. Tectonics 7:557-567.

Bouhallier, H.; Chardon, D.; and Choukroune, P. 1995. Strain patterns in Archaean dome-and-basin structures: the Dharwar craton (Karnataka, South India). Earth Planet. Sci. Lett. 135:57-75.

Brun, J. P.; Gapais, D.; and Le Theoff, B. 1981. The man- tled gneiss domes of Kuopo (Finland): interfering diapirs. Tectonophysics 74:283-304.

Brun, J. P., and Van Den Driessche, J. 1994. Extensional gneiss domes and detachment faults: structure and kinematics. Bull. Soc. Geol. Fr. 165:519-530.

Buck, R. 1991. Modes of continental lithospheric extension. J. Geophys. Res. 96:161-178.

Cocks, L. R. M., and Fortey, R. A. 1982. Faunal evidence for oceanic separations in the Palaeozoic of Britain. J. Geol. Soc. 139:465-478.

Coney, P., and Harms, T. A. 1984. Cordilleran metamorphic core complexes: Cenozoic extensional relics of Mesozoic compression. Geology 12:550-554.

Dallmeyer, R. D.; Martínez Catalán, J. R.; Arenas, R.; Gil Ibarguchi, J. I.; Gutierrez-Alonso, G.; Farias, P.; Bastida, F.; and Aller, J. 1997. Diachronous Variscan tectonothermal activity in the NW Iberian Massif: evidence from ${ }^{40} \mathrm{Ar} /{ }^{39} \mathrm{Ar}$ dating of regional fabrics. Tectonophysics 277:307-337.

Dewey, J. F. 1988. Extensional collapse of orogens. Tectonics 7:1123-1139.

Díaz García, F.; Arenas, R.; Martínez Catalán, J. R.; del Tanago, J. G.; and Dunning, G. R. 1999. Tectonic evolution of the Careon ophiolite (northwest Spain): a remnant of oceanic lithosphere in the Variscan belt. J. Geol. 107:587-605.

Díez Balda, M. A.; Martínez Catalán, J. R.; and Ayarza, P. 1995. Syn-collisional extensional collapse parallel to the orogenic trend in a domain of steep tectonics: the Salamanca detachment zone /Central Iberian Zone, Spain). J. Struct. Geol. 17:163-182.

Díez Fernández, R. 2011. Evolución estructural y cinemática de una corteza continental subducida: la Unidad de Malpica-Tui (NO del Macizo Ibérico). Nova Terra 40. A Coruña, Spain, Instituto Universitario de Xeoloxía Isidro Parga Pondal, 228 p.

Díez Fernández, R.; Castiñeiras, P.; and Gómez Barreiro, J. 2012a. Age constraints on Lower Paleozoic convection system: magmatic events in the NW Iberian Gondwana margin. Gondwana Res., doi:10.1016/ j.gr.2011.07.028.

Díez Fernández, R., and Martínez Catalán, J. R. 2009. 3D analysis of an Ordovician igneous ensemble: a complex magmatic structure hidden in a polydeformed allochthonous Variscan unit. J. Struct. Geol. 31:222236.

Díez Fernández, R.; Martínez Catalán, J. R.; Arenas, R.; and Abati, J. 2012b. The onset of the assembly of Pangaea in NW Iberia: constraints on the kinematics of continental subduction. Gondwana Res., doi:10.1016/ j.gr.2011.08.004.

Díez Fernández, R.; Martínez Catalán, J. R.; Arenas Mar- 
tín, R.; and Abati Gómez, J. 2011. Tectonic evolution of a continental subduction-exhumation channel: Variscan structure of the basal allochthonous units in NW Spain. Tectonics 30:TC3009.

Díez Fernández, R.; Martínez Catalán, J. R.; Gerdes, A.; Abati, J.; Arenas, R.; and Fernández-Suárez, J. 2010. $\mathrm{U}-\mathrm{Pb}$ ages of detrital zircons from the Basal allochthonous units of NW Iberia: provenance and paleoposition on the northern margin of Gondwana during the Neoproterozoic and Paleozoic. Gondwana Res. 18: 385-399.

Díez Montes, A. 2007. La geología del Dominio "Ollo de Sapo" en las comarcas de Sanabria y Terra do Bolo. Nova Terra 34. A Coruña, Spain, Instituto Universitario de Xeoloxía Isidro Parga Pondal, 494 p.

England, P., and Houseman, G. 1989. Extension during continental convergence, with application to the Tibetan plateau. J. Geophys. Res. Solid Earth Planets 94: $17,561-17,579$.

England, P. C. 1982. Some numerical investigations of large scale continental deformation. In Hsü, K. J., ed. Mountain building processes. New York, Academic Press, p. 129-139.

Escuder Viruete, J. E. 1999. Evolución tectonotermal del Domo Gnéisico del Tormes, Salamanca, NO del Macizo Ibérico. Nova Terra 15. A Coruña, Spain, Instituto Universitario de Xeoloxía Isidro Parga Pondal, 385 p.

Escuder Viruete, J. E.; Arenas, R.; and Martínez Catalán, J. R. 1994. Tectonothermal evolution associated with Variscan crustal extension in the Tormes gneiss dome (NW Salamanca, Iberian Massif, Spain). Tectonophysics 238:117-138.

Faure, M.; Lardeaux, J.-M.; and Ledru, P. 2009. A review of the pre-Permian geology of the Variscan French Massif Central. C. R. Geosci. 341:202-213.

Fernández-Suárez, J.; Gutiérrez-Alonso, G.; and Jeffries, T. E. 2002. The importance of along-margin terrane transport in northern Gondwana: insights from detrital zircon parentage in Neoproterozoic rocks from Iberia and Brittany. Earth Planet. Sci. Lett. 204:75-88.

Fortey, R. A., and Cocks, L. R. M. 2003. Palaeontological evidence bearing on global Ordovician-Silurian continental reconstructions. Earth-Sci. Rev. 61:245-307.

Fossen, H., and Tikoff, B. 1993. The deformation matrix for simultaneous simple shearing, pure shearing and volume change, and its application to transpression transtension tectonics. J. Struct. Geol. 15:413-422.

Gapais, D.; Pêcher, A.; Gilbert, E.; and Ballevre, M. 1992. Synconvergence spreading of the higher Himalaya crystallines in Ladakh. Tectonics 11:1045-1056.

Gómez Barreiro, J. 2007. La Unidad de Fornás: Evolución tectonometamórfica del SO del Complejo de Órdenes. Nova Terra 32. A Coruña, Spain, Instituto Universitario de Xeoloxía Isidro Parga Pondal, 291 p.

Gómez Barreiro, J.; Martínez Catalán, J. R.; Arenas, R.; Castiñeiras, P.; Abati, J.; Díaz García, F.; and Wijbrans, J. R. 2007. Tectonic evolution of the upper allochthon of the Órdenes Complex (northwestern Iberian Massif): structural constraints to a polyorogenic periGondwanan terrane. In Linnemann, U.; Nance, R. D.;
Kraft, P.; and Zulauf, G., eds. The evolution of the Rheic Ocean: from Avalonian-Cadomian active margin to Alleghenian-Variscan collision. Geol. Soc. Am. Spec. Pap. 423:315-332.

Gómez Barreiro, J.; Martínez Catalán, J. R.; Díez Fernández, R.; Arenas, R.; and Díaz García, F. 2010. Upper crust reworking during gravitational collapse: the Bembibre-Pico Sacro detachment system (NW Iberia). J. Geol. Soc. 167:769-784.

González Cuadra, P. 2007. La Unidad de Corredoiras (Complejo de Órdenes, Galicia): Evolución estructural y Metamórfica. Nova Terra 33. A Coruña, Spain, Instituto Universitario de Xeoloxía Isidro Parga Pondal, $254 \mathrm{p}$.

González Cuadra, P.; Díaz García, F.; and Cuesta, A. 2006. Estructura del granito de Beariz (Ourense, Galicia). Geogaceta 40:151-154.

Hacker, B. R.; Andersen, T. B.; Johnston, S.; KylanderClark, A. R. C.; Peterman, E. M.; Walsh, E. O.; and Young, D. 2010. High-temperature deformation during continental-margin subduction and exhumation: the ultrahigh-pressure Western Gneiss Region of Norway. Tectonophysics 480:149-171.

Holdaway, M. J. 1971. Stability of andalusite and aluminum silicate phase diagram. Am. J. Sci. 271:97-131.

Kaufman, P. S., and Royden, L. H. 1994. Lower crustal flow in an extensional setting: constraints from the Halloran Hills regions, eastern Mojave Desert, California. J. Geophys. Res. 99:723-739.

Krawczyk, C. M.; McCann, T.; Cocks, L. R. M.; England, R.; McBride, J.; and Wybraniez, S. 2008. Caledonian tectonics. In McCann, T., ed. The geology of Central Europe. Geol. Soc. Lond., p. 301-381.

Krohe, A. 1998. Extending a thickened crustal bulge: toward a new geodynamic evolution model of the Paleozoic NW Bohemian Massif, German continental deep drilling site (SE Germany). Earth-Sci. Rev. 44:95145.

Krohe, A., and Eisbacher, G. 1988. Oblique crustal detachment in the Variscan Schwarzwald, southwestern Germany. Geol. Rundsch. 77:25-43.

Lagarde, J.-L.; Dallain, C.; Ledru, P.; and Courrioux, G. 1994. Strain patterns within the late Variscan granitic dome of Velay, French Massif Central. J. Struct. Geol. 16:839-852.

Le Bayon, B., and Ballevre, M. 2006. Deformation history of a subducted continental crust (Gran Paradiso, Western Alps): continuing crustal shortening during exhumation. J. Struct. Geol. 28:793-815.

Ledru, P.; Courrioux, G.; Dallain, C.; Lardeaux, J. M.; Montel, J. M.; Vanderhaeghe, O.; and Vitel, G. 2001. The Velay dome (French Massif Central): melt generation and granite emplacement during orogenic evolution. Tectonophysics 342:207-237.

Lister, G. S., and Davis, G. A. 1989. The origin of metamorphic core complexes and detachment faults formed during Tertiary continental extension in the northern Colorado River region, U.S.A. J. Struct. Geol. 11:65-94.

Llana Fúnez, S. 2001. La estructura de la Unidad de Mal- 
pica-Tui (Cordillera Varisca en Iberia). Serie Tesis Doctorales 1. Madrid, Instituto Geológico y Minero de España.

Llana-Fúnez, S., and Marcos, A. 2001. The MalpicaLamego Line: a major crustal-scale shear zone in the Variscan belt of Iberia. J. Struct. Geol. 23:1015-1030.

- 2002. Structural record during exhumation and emplacement of high-pressure low- to intermediatetemperature rocks in the Malpica-Tui unit (Variscan Belt of Iberia). In Martínez Catalán, J. R.; Hatcher, R. D.; Arenas, R.; and Díaz García, F., eds. Variscan-Appalachian dynamics: the building of the Late Paleozoic basement. Geol. Soc. Am. Spec. Pap., p. 125-142.

López-Carmona, A.; Abati, J.; and Reche, J. 2010. Petrologic modeling of chloritoid-glaucophane schists from the NW Iberian Massif. Gondwana Res. 17:377391.

Malavieille, J. 1987. Kinematics of compressional and extensional ductile shearing deformation in a metamorphic core complex of the northeastern basin and range. J. Struct. Geol. 9:541-554.

Malavieille, J.; Guihot, P.; Costa, S.; Lardeaux, J. M.; and Gardien, V. 1990. Collapse of the thickened Variscan crust in the French Massif Central: Mont Pilat extensional shear zone and St. Etienne Late Carboniferous basin. Tectonophysics 177:139-149.

Marques, F. O.; Ribeiro, A.; and Munhá, J. M. 1996. Geodynamic evolution of the Continental Allochthonous Terrane (CAT) of the Bragança Nappe Complex, NE Portugal. Tectonics 15:747-762.

Marquínez García, J. L. 1984. La geología del área esquistosa de Galicia Central (Cordillera Herciniana, NW de España). Mem. Inst. Geol. Min. Esp. 100:231.

Martínez Catalán, J. R. 1990. A non-cylindrical model for the northwest Iberian allochthonous terranes and their equivalents in the Hercynian belt of Western Europe. Tectonophysics 179:253-272.

- 2011. Are the oroclines of the Variscan belt related to late Variscan strike-slip tectonics? Terra Nova 23:241-247.

Martínez Catalán, J. R.; Arenas, R.; Abati, J.; Sánchez Martínez, S.; Díaz García, F.; Fernández-Suárez, J.; González Cuadra, P.; et al. 2009. A rootless suture and the loss of the roots of a mountain chain: the Variscan belt of NW Iberia. C. R. Geosci. 341:114-126.

Martínez Catalán, J. R.; Arenas, R.; Díaz García, F.; and Abati, J. 1997. Variscan accretionary complex of northwest Iberia: terrane correlation and succession of tectonothermal events. Geology 25:1103-1106.

Martínez Catalán, J. R.; Arenas, R.; Díaz García, F.; Gómez Barreiro, J.; González Cuadra, P.; Abati, J.; Castiñeiras, P.; et al. 2007. Space and time in the tectonic evolution of the northwestern Iberian Massif: implications for the Variscan belt. In Hatcher, R. D.; Carlson, M. P.; Mcbride, J. H.; and Martínez Catalán, J. R., eds. 4-D framework of continental crust. Boulder, CO, Geol. Soc. Am. Mem., p. 403-423.

Martínez Catalán, J. R.; Arenas, R.; Díaz García, F.; Rubio Pascual, F. J.; Abati, J.; and Marquínez García, J. 1996. Variscan exhumation of a subducted Paleozoic con- tinental margin: the basal units of the Ordenes Complex, Galicia, NW Spain. Tectonics 15:106-121.

Martínez Catalán, J. R.; Arenas, R.; and Díez Balda, M. A. 2003. Large extensional structures developed during emplacement of a crystalline thrust sheet: the Mondoñedo nappe (NW Spain). J. Struct. Geol. 25: 1815-1839.

Martínez Catalán, J. R.; Díaz García, F.; Arenas, R.; Abati, J.; Castineiras, P.; González Cuadra, P.; Gómez Barreiro, J.; and Rubio Pascual, F. J. 2002. Thrust and detachment systems in the Ordenes Complex (northwestern Spain): implications for the Variscan-Appalachian geodynamics. In Martínez Catalán, J. R.; Hatcher, R. D.; Arenas, R.; and Díaz García, F., eds. Variscan-Appalachian dynamics: the building of the Late Paleozoic basement. Geol. Soc. Am. Spec. Pap., p. 163-182.

Matte, P. 1991. Accretionary history and crustal evolution of the Variscan belt in Western Europe. Tectonophysics 196:309-337.

McCaffrey, K. 1992. Oblique plate convergence, slip vectors, and forearc deformation. J. Geophys. Res. 97: 8905-8915.

McCaffrey, K.; Zwick, P. C.; Bock, Y.; Prawirodirdjo, L.; Genrich, J. F.; Stevens, C. W.; Puntodewo, S. S. O.; and Subarya, C. 2000. Strain partitioning during oblique plate convergence in northern Sumatra: geodetic and seismologic constraints and numerical modeling. J. Geophys. Res. 105:28,363-28,376.

McCaffrey, R. 1996. Slip partitioning at convergent plate boundaries of SE Asia. Geol. Soc. Lond. Spec. Publ. 106:3-18.

McClay, K. R.; Norton, M. G.; Coney, P.; and Davis, G. H. 1986. Collapse of the Caledonian orogen and the old red sandstone. Nature 323:147-149.

McFadden, R. R.; Siddoway, C. S.; Teyssier, C.; and Fanning, C. M. 2010. Cretaceous oblique extensional deformation and magma accumulation in the Fosdick Mountains migmatite-cored gneiss dome, West Antarctica. Tectonics 29:TC4022.

Ménard, G., and Molnar, P. 1988. Collapse of a Hercynian Tibetan Plateau into a late Paleozoic European Basin and range province. Nature 334:235-237.

Miller, J. A.; Holdsworth, R. E.; Buick, I. S.; and Hand, M. 2001. Continental reactivation and reworking. Geol. Soc. Lond. Spec. Publ. 184.

Molnar, P., and Chen, W. P. 1982. Seismicity and mountain building. In Hsü, K. J., ed. Mountain building processes. New York, Academic Press, p. 41-57.

- 1983. Focal depths and fault plane solutions earthquakes under the Tibetan plateau. J. Geophys. Res. 88:1180-1196.

Molnar, P., and Lyon Caen, H. 1988. Some simple physical aspects of the support, structure, and evolution of mountain belts. Geol. Soc. Am. Spec. Pap. 218:179207.

Ord, A., and Hobbs, B. E. 1989. The strength of the continental crust, detachment zones and the development of plastic instabilities. Tectonophysics 158:269289.

Paterson, S. R.; Vernon, R. H.; and Tobisch, O. T. 1989. 
A review of criteria for the identification of magmatic and tectonic foliations in granitoids. J. Struct. Geol. 11:349-363.

Platt, J. P. 1986. Dynamics of orogenic wedges and the uplift of high-pressure metamorphic rocks. Geol. Soc. Am. Bull. 97:1037-1053.

- 1993. Mechanics of oblique convergence. J. Geophys. Res. 98:16239-16256.

Platt, J. P., and England, P. C. 1994. Convective removal of lithosphere beneath mountain belts: thermal and mechanical consequences. Am. J. Sci. 294:307-336.

Powell, R., and Holland, T. J. B. 1990. Calculated mineral equilibria in the pelite system, KFMASH $\left(\mathrm{K}_{2} \mathrm{O}-\mathrm{FeO}\right.$ $\mathrm{MgO}-\mathrm{Al}_{2} \mathrm{O}_{3}-\mathrm{SiO}_{2}-\mathrm{H}_{2} \mathrm{O}$. Am. Mineral. 75:367-380.

Ratschbacher, L.; Frisch, W.; Neubauer, F.; Schmid, S. M.; and Neugebauer, J. 1989. Extension in compressional orogenic belts: the eastern Alps. Geology 17:404-407.

Rey, P.; Vanderhaeghe, O.; and Teyssier, C. 2001. Gravitational collapse of the continental crust: definition, regimes and modes. Tectonophysics 342:435-449.

Ribeiro, A.; Pereira, E.; and Dias, R. 1990. Structure in the northwest of the Iberian Peninsula. In Dallmeyer, R. D., and Martínez García, E., eds. Pre-Mesozoic geology of Iberia. Berlin, Springer, p. 220-236.

Rodríguez, J.; Cosca, M. A.; Gil Ibarguchi, J. I.; and Dallmeyer, R. D. 2003. Strain partitioning and preservation of ${ }^{40} \mathrm{Ar} /{ }^{39} \mathrm{Ar}$ ages during Variscan exhumation of a subducted crust (Malpica-Tui Complex, NW Spain). Lithos 70:111-139.

Rubio Pascual, F.; Arenas, R.; Díaz García, F.; Martínez Catalán, J. R.; and Abati, J. 2002. Contrasting highpressure metabasites from the Santiago unit (Ordenes Complex, northwestern Iberian Massif, Spain). In Martínez Catalán, J. R.; Hatcher, R. D.; Arenas, R.; and Díaz García, F., eds. Variscan-Appalachian dynamics: the building of the Late Paleozoic basement. Geol. Soc. Am. Spec. Pap., p. 105-124.

Ruppel, C. 1995. Extensional processes in continental lithosphere. J. Geophys. Res. 100:24,187-24,215.

Sánchez Martínez, S.; Arenas, R.; Fernández-Suárez, J.; and Jeffries, T. E. 2009. From Rodinia to Pangaea: ophiolites from NW Iberia as witness for a long-lived continental margin. Geol. Soc. Lond. Spec. Publ. 327:317341.

Sanderson, D. J., and Marchini, W. R. D. 1984. Transpression. J. Struct. Geol. 6:449-458.

Shelley, D., and Bossiere, G. 2000. A new model for the Hercynian Orogen of Gondwanan France and Iberia. J. Struct. Geol. 22:757-776.
2002. Megadisplacements and the Hercynian Orogen of Gondwanan France and Iberia. Geol. Soc. Am Spec. Pap. 364:209-222.

Stampfli, G. M., and Borel, G. D. 2002. A plate tectonic model for the Paleozoic and Mesozoic constrained by dynamic plate boundaries and restored synthetic oceanic isochrons. Earth Planet. Sci. Lett. 196:17-33.

Tapponnier, P., and Molnar, P. 1979. Active faulting and Cenozoic tectonics of the Tien Shan, Mongolia, and Baykal regions. J. Geophys. Res. 84:3425-3459.

Tapponnier, P.; Peltzer, G.; Le Dain, A. Y.; Armijo, R.; and Cobbold, P. 1982. Propagating extrusion tectonics in Asia: new insights from simple experiments with plasticine. Geology 10:611-616.

Tikoff, B., and Peterson, K. 1998. Physical experiments of transpressional folding. J. Struct. Geol. 20:661-672.

Torsvik, T. H.; Smethurst, M. A.; Meert, J. G.; Van der Voo, R.; McKerrow, W. S.; Brasier, M. D.; Sturt, B. A.; and Walderhaug, H. J. 1996. Continental break-up and collision in the Neoproterozoic and Palaeozoic: a tale of Baltica and Laurentia. Earth-Sci. Rev. 40:229-258.

Vanderhaeghe, O., and Teyssier, C. 1997. Formation of the Shuswap metamorphic core complex during lateorogenic collapse of the Canadian Cordillera: role of ductile thinning and partial melting of the mid- to lower crust. Geodin. Acta 10:41-58.

- 2001. Crustal-scale rheological transitions during late-orogenic collapse. Tectonophysics 335:211-228.

Villar Alonso, P. M. 1990. Estructura del Antiforme de Villadepera (Zamora). MSc thesis, Universidad de Salamanca.

Wdowinski, S., and Axen, G. J. 1992. Isostatic rebound due to tectonic denudation: a viscous flow model of a layered lithosphere. Tectonics 11:303-315.

Whitney, D. L.; Teyssier, C.; and Vanderhaeghe, O. 2004. Gneiss domes and crustal flow. Geol. Soc. Am. Spec. Pap. 380:15-33.

Winchester, J. A.; Pharaoh, T. C.; and Verniers, J. 2002. Palaeozoic amalgamation of Central Europe: an introduction and synthesis of new results from recent geological and geophysical investigations. Geol. Soc. Spec. Publ. 201.

Wu, W.-N.; Hsu, S.-K.; Lo, C.-L.; Chen, H.-W.; and Ma, K.-F. 2009. Plate convergence at the westernmost Philippine Sea Plate. Tectonophysics 466:162-169.

Yin, A. 2004. Gneiss domes and gneiss dome systems. Geol. Soc. Am. Spec. Pap. 380:1-14. 